\title{
GRANITO POJUCA, SERRA DOS CARAJÁS (PA): COMPOSIÇÃO MINERALÓGICA, QUIIMICA MINERAL E CONTROLES QUIIMICOS DA ALTERAÇÃO HIDROTERMAL
}

\author{
RAIMUNDO NETUNO VILLAS
}

\begin{abstract}
THE POJUCA GRANITE: MINERALOGICAL COMPOSITION, MINERAL CHEMISTRY AND CHEMICAL CONTROLS OF THE HYDROTHERMAL ALTERATION The Pojuca granite is one of the intrusions formed during the anorogenic acid magmatic event that occurred in the Carajás Ridge region around 1.9 Ga. With a small outcropping área, it extends laterally under the Archean Igarapé Pojuca Group host rocks. Petrographic studies combined with microprobe mineral data allowed not only a more accurate determination of the phases but also the identification of rare specimens. The Pojuca body presents leuco- to hololeucocratic rocks with mafic mineral contents that seldom are higher than 5\%. Alkali-feldspar granites with subordinate syeno- and monzogranites are the rock types described. Albite, potassic feldspar and quartz are the main mineral constituents, whereas biotite, allanite and hornblende, in this order of abundance, are the varietal phases. Among the primary accessory minerais occur zircon, apatite, titanite, thorite/uranothorite, policrase, and microlite. Topaz is uncommon, although it and tourmaline appear to denote the transition between the pneumatolitic and the hydrothermal stages. About 30 secondary phases have been identified, many of them with a large composition variation. A few have equivalent counterparts in the primary assemblages as to indicate that the aqueous solutions and the granitic rocks approached an overall equilibrium. Several minerais, however, resulted from local equilibria in which the destroyed mineral or the fluid compositions were decisive for their formation. Ca-, Y- and REE-rich minerais (hellandite, gadolinite, synchisite, caysichite?) stand out in the hydrothermal assemblages and their common occurrence in veins/veinlets implies a significant mobility of those elements in the Pojuca system. As the REE distribution patterns in both primary and seconday minor phases are very similar, it seems very convincing that igneous accessory minerais were the major source for the lanthanides. Likewise, they probably were also the source for yttrium especially allanite $\left(0,11-0,82 \% \mathrm{Y}_{2} \mathrm{O}_{3}\right)$ and policrase $\left(18,15 \% \mathrm{Y}_{2} \mathrm{O}_{3}\right)$. Regarding calcium, it is suggested, on the basis of mass balance calculations, that the host amphibolites might have provided most of it to account for the observed amounts of hydrothermal Ca-rich minerais.

Keywords:Pojuca. granite, Carajás Province, mineralogy, mineral chemistry, hydrothermal alteration
\end{abstract}

RESUMO O granito Pojuca é uma das intrusões que registram o magmatismo ácido anorogênico ocorrido na região da Serra dos Carajás por volta de 1,9 Ga. De pequena área aflorante, estende-se lateralmente por sob as rochas do Grupo Igarapé Bahia, de idade arquena, nas quais é intrusivo. Nesse corpo granítico foram realizados estudos petrográficos e determinadas as composições dos minerais por microssonda, que permitiram não só precisar melhor algumas variedades como também identificar espécimens minerais raros. A intrusão Pojuca apresenta rochas leuco a hololeucocráticas com teores de minerais máficos raramente superiores a $5 \%$, destacando-se álcali-feldspato granitos com sieno e monzogranitos subordinados. Albita, feldspato potássico e quartzo são os principais constituintes, enquanto biotita, alanita e hornblenda, nesta ordem de abundância, são as fases varietais. No grupo dos minerais acessórios primários figuram zircão, apatita, titanita, torita/uranotorita, policrásio e microlita. Topázio é pouco expressivo e parece marcar, junto com a turmalina, a transição entre os estágios pneumatolítico e hidrotermal. Foram identificadas cerca de 30 fases secundárias, muitas delas com ampla variação composicional. Algumas são equivalentes às da associação primária, o que indica que as soluções aquosas e o granito se aproximaram de um equilíbrio geral. Muitos minerais, porém, resultaram de equilíbrios locais controlados prioritariamente pela composicão dos minerais destruídos ou pela composição dos fluidos. Sobressaem, na associação hidrotermal, minerais ricos em Ca, Y e/ou ETR (hellandita, gadolinita, sinchisita, caysichita?), vários dos quais estão presentes em veios/vênulas, mostrando que houve grande mobilidade desses elementos no sistema Pojuca. Como o padrão de distribuição dos ETR entre fases primárias e secundárias é muito semelhante, pode-se deduzir que a fonte dos lantanídeos foram muito provavelmente os minerais acessórios ígneos, que também o foram para o $\mathrm{Y}$, em especial a allanita $\left(0,11-0,82 \% \mathrm{Y}_{2} \mathrm{O}_{3}\right)$ e o policrásio $\left(18,15 \% \mathrm{Y}_{2} \mathrm{O}_{3}\right)$. Quanto ao Ca, sugere-se, com base em cálculos de balanço de massa, que houve apreciável aporte ao granito a partir dos anfibolitos encaixantes para precipitar as quantidades observadas de minerais ricos nesse elemento.

Palavras-chaves: granito Pojuca, Província Carajás, mineralogia, química mineral, alteração hidrotermal

INTRODUC̃̃O Em tempos proterozóicos, estendendo-se por quase um bilhão de anos, teve lugar, no Cráton Amazônico, uma das maiores granitogêneses de que se tem registro na história geológica da crosta terrestre. Dentro da Província Amazónia Central (Teixeira et al. 1989), na porção oriental desse cráton, esse magmatismo foi temporalmente mais restrito, com duração de cerca de $350 \mathrm{Ma}$, e está representado por uma suíte granítica anorogênica, que consiste de intrusões de dimensões variadas, a maioria de porte batolítico e algumas mineralizadas com Sn ou W.

Muitas dessas intrusões vêm, desde há muito, sendo sistematicamente investigadas (Dall'Agnol et al 1986, 1987, 1988, 1994a, 1994b, Magalhães \& Dali'Agnol 1992, Scaillet et al 1995, Rios 1995, Rios et al. 1995a e 1995b). Nos últimos anos a atenção também tem se voltado ao corpo Pojuca, que, apesar de já ter sido datado há algum tempo (Machado et al 1991), só recentemente foi caracterizado petrológica e geoquimicámente (Horbe 1998). Está localizado a cerca de $50 \mathrm{Km}$ a NW da cidade de Carajás (Fig. 1), tendo-se alojado em uma sequência vulcanossedimentar mineralizada com sulfetos de $\mathrm{Cu}$ e $\mathrm{Zn}$, parte dos quais foi remobilizada durante o evento intrusjvo e reprecipitada nas fraturas abertas na cúpula do granito.

$\mathrm{O}$ presente trabalho faz parte de uma pesquisa mais ampla que busca estudar o paleossistema hidrotermal responsável pela alteração e mineralização presentes no granito Pojuca. As amostras estudadas provieram de testemunhos de sondagem realizados pela DOCEGEO. Em superfície, além da escassez de afloramentos, o corpo intrusivo acha-se bastante intemperizado e coberto por densa vegetação.

Análises petrográficas preliminares revelaram a presença de inúmeros minerais que não puderam ser identificados pelos métodos ópticos convencionais. Alguns são raros, enquanto outros, ainda que em quantidades acessórias, ocorrem com maior frequência. Um minucioso trabalho com microssonda eletrônica permitiu identificálos, registrando-se cerca de 10 diferentes minerais dentre fases magmáticas e hidrotermais.

Essa diversidade mineralógica justificou o presente trabalho e dá destaque ao granito Pojuca como membro da suíte anorogênica pré- sente na Província Amazônia Central. Como essa intrusão acha-se hidrotermalmente alterada, o trabalho também foi dirigido no sentido de avaliar o papel das soluções aquosas, das rochas encaixantes e do próprio granito na formação, abundância e distribuição espacial dos minerais de alteração.

A SUÍTE GRANÍTICA ANOROGÊNICA DA PROVÍNCIA AMAZÓNIA CENTRAL As intrusões graníticas anorogênicas da Província Amazónia Central guardam muitas caracteristicas em comum, mas, ao mesmo tempo, apresentam importantes variações texturais, geoquímicas e geocronológicas que apontam para diferenças nas fontes dos magmas, história da cristalização e idade de alojamento (Dall'Agnol et al. 1994a).

Na porção sul dessa província, cujos limites mais ou menos coincidem com o Distrito Metalogenético de Carajás, já foram mapeados cerca de duas dezenas de corpos graníticos anorogênicos. Embora haja uma concentração maior na região central desse distrito, a leste do curso médio-inferior do rio Fresco, esses corpos têm uma distribuição espacial muito abrangente e cortam praticamente todas as unidades arqueanas e proterozóicas que lá ocorrem. Dados geocronológicos apontam idades U-Pb por volta de 1,9 Ga para esses corpos (Wirth et ai 1986, Machado et al. 1991), as quais marcam o evento magmático final da evolução desse segmento crustal no Pré-Cambriaho.

Segundo Dall'Agnol et al. (1994a), essas intrusões ocorreram em regime tectônico distensivo e alojaram-se a profundidades correspondendo a pressões de 0,5 a 2 kbar. Mostram contatos bem definidos e discordantes com relação às rochas encaixantes, normalmente desenvolvendo auréolas de metamorfismo de contato que chega a atingir a fácies hornblenda hornfels. O magmatismo anorogênico produziu rochas essencialmente hololeucocráticas a leucocráticas de composição sieno a monzo-granítica dominante. Quimicamente elas enquadram-se na série sub-alcalina a alcalina com saturação em alumina que aponta terem sido oriundas de magmas metaluminosos a peraluminosos. Outras características geoquímicas permitem classificar os granitos anorogênicos da Província Amazónia Central como do tipo A

* Departamento de Geologia, Centro de Geociências, Universidade Federal do Pará (UFPA), Av. Augusto Corrêa 1, CEP 66075-900, Belém, PA, Brasil. Fax

(091) 211.1609, Fone (091) 211.1414, e-mail: netuno@ufpa.br 

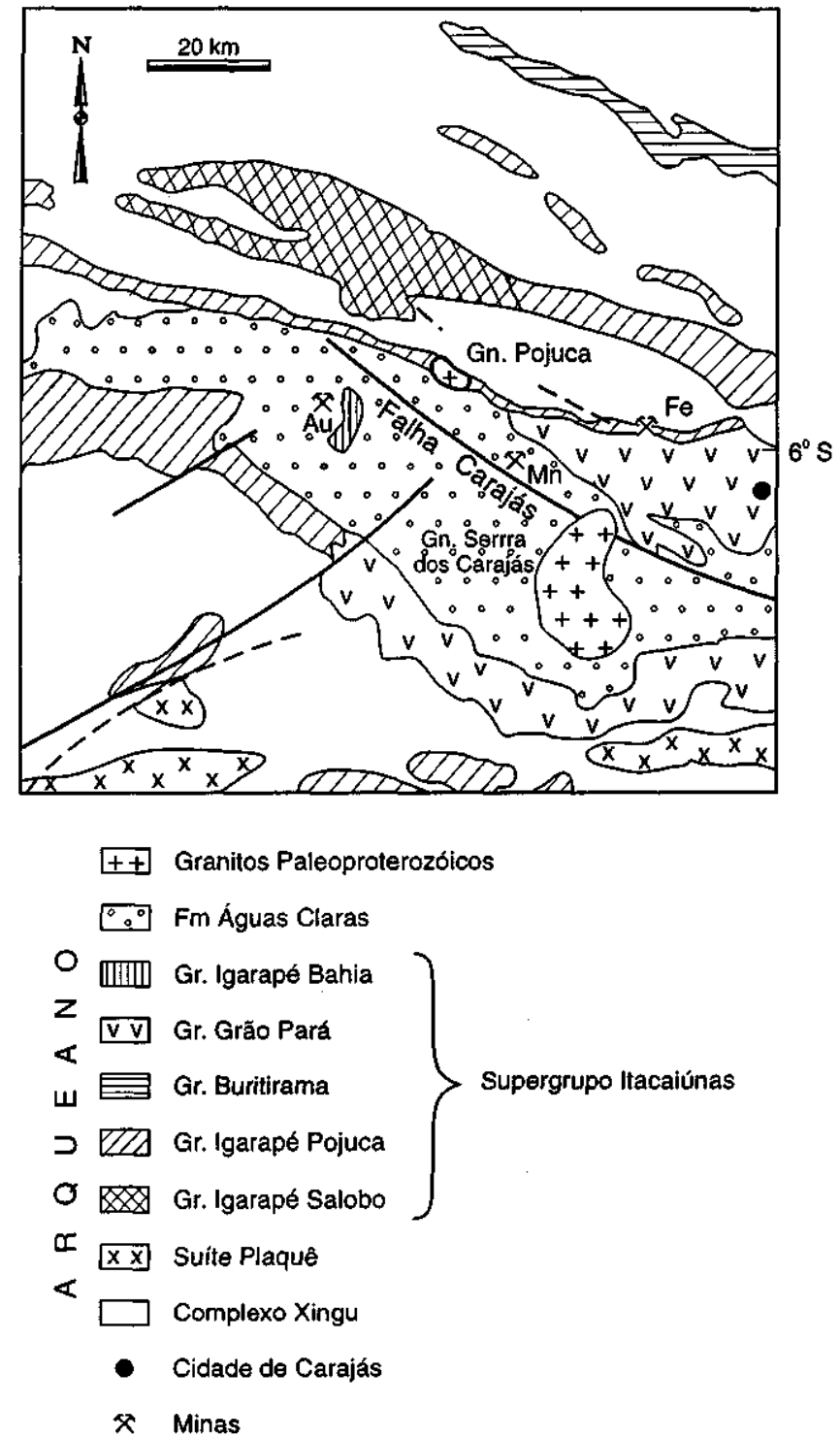

Figura l - Mapa geológico simplificado de parte do Distrito Metalogenético de Carajás (PA) com a localização da área de ocorrência do granito Pojucá (modificado de Docegeo 1988).

e de formação intraplaca, ambiente este em que a contribuição crustal aos magmas-fonte foi importante, como indicam as moderadas a altas razões iniciais de $\mathrm{Sr}$ entre 0,704 e 0,716 . Do ponto de vista metalogenético, ocorrem tanto granitos especializados como não-especializados, os primeiros mineralizados com cassiterita ou wolframita. Mineralizações sub-econômicas de $\mathrm{Cu}$ e Mo estão presentes em várias dessas intrusões.

O GRANITO POJUCA O granito Pojuca aflora, na área homónima, em três janelas com formas e tamanhos variados, as quais devem ser a expressão, em superfície, de um único corpo. A maior dessas janelas tem área inferior a $10 \mathrm{~km}^{2}$ e forma de uma elipse alongada (Fig. 2). Os furos de sondagem alcançaram o corpo intrusivo a profundidades variadas, em geral superiores a $200 \mathrm{~m}$, mas raramente tendo nele penetrado mais de $20 \mathrm{~m}$. As amostras estudadas são de testemunhos de 13 desses furos.

$\mathrm{Na}$ área Pojuca ocorre uma mineralização de sulfetos vulcanogênicos de $\mathrm{Cu}-\mathrm{Zn}$, que está contida em quatro depósitos, denominados de Corpos 1, 2, 3 e 4 (Docegeo 1984). A maioria dos furos estudados pertence ao Corpo Quatro, porém os maiores intervalos em rochas graníticas foram obtidos de furos feitos nos outros três corpos.

Contexto Geológico O granito Pojuca é intrusivo no Grupo Igarapé Pojuca, que, à semelhança do Grupo Igarapé Salobo, de
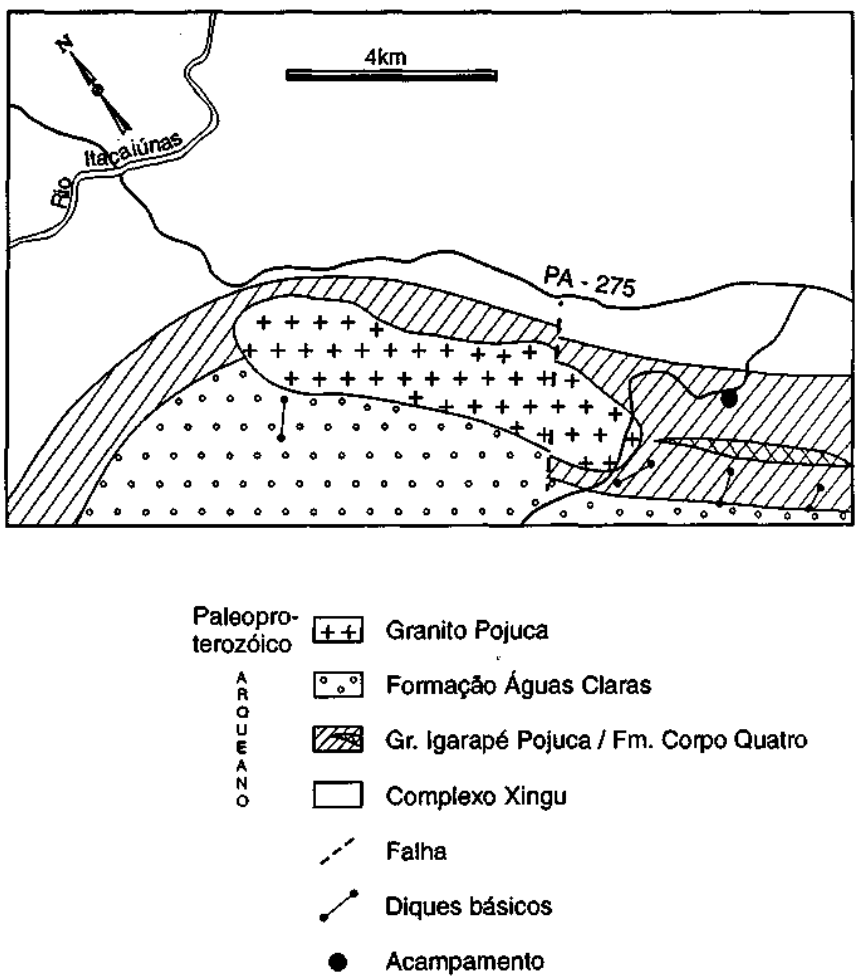

Figura 2 - Mapa geológico simplificado da área Pojuca, região de Carajás, Pará (modificado de Macambira et al. 1990)

ocorrência mais a noroeste, forma serras alongadas na direção NW-SE. Juntas com os grupos Grão Pará, Igarapé Bahia e Buritirania, aquelas duas unidades litoestratigráficas compõem o Supergrupo Itacaiúnas (Docegeo 1988), de idade arqueana, o qual contém as mais expressivas reservas minerais do Distrito Metalogenético Carajás. Essas unidades estão sobrepostas às rochas do Complexo Xingu e foram submetidas a diferentes regimes deformacionais dúcteis, os de mais alta temperatura atingindo as rochas do Grupo Igarapé Salobo e os de mais baixa temperatura aquelas dos grupos Igarapé Pojuca e Grão Pará (Pinheiro \& Holdsworth 1997). Desmembrada do Complexo Xingu destaca-se, ao sul da Serra dos Carajás, a Suíte Plaque (Araújo et al. 1988), que consiste de corpos granitóides deformados, de idade arqueana, alongados segundo a direção geral E-W.

As rochas que hoje compõem o Grupo Igarapé Pojuca foram informalmente incluídas em quatro unidades (Medeiros Neto \& Villas 1985), as quais, da base para o topo, apresentam: 1) anfibolitos, constituídos predominantemente de hornblenda e andesina, com intercalações de biotita-anfibólio-granada xistos e de lentes irregulares de antofilita e cordierita; 2) formação ferrífera bandada, em cuja porção inferior ocorrem metassilexitos com intercalações anfíbolíticas associadas a concentrações de sulfetos e/ou magnetita, a leitos granatíferos e de Fe-anfibólio xistos com granada e /ou cordierita, além de fragmentos de metassilexitos e de sulfetos; a parte superior é constituída por anfibólio xistos com quantidades variadas de granada, biotita e fragmentos de metassilexito e de bandas de sulfetos; 3) anfibolitos compostos predominantemente por andesina ripiforme e hornblenda, contendo lentes irregulares de antofilita e cordierita; e 4) metarenitos grauváquicos a ortoquartzíticos e metassiltitos com finas intercalações de filitos.

As duas primeiras unidades correspondem à Formação Corpo Quatro com espessura média de cerca de 100 m (Docegeo 1988), tratando-se de rochas básicas intercaladas com rochas sedimentares químicas e pelíticas, localmente retrabalhadas, que, a despeito do metamorfismo de fácies anfibolito médio, ainda preservam algumas feições deposicionais primárias.

O granito Pojuca é também intrusivo na Formação Águas Claras, que repousa discordantemente sobre o Grupo Igarapé Pojuca e constitui uma cobertura elástica dominada por arenitos e siltitos, de incipiente grau metamórfíco. Auréolas de contato, marcadas por rochas à cordierita e à antofilita, e de distribuição irregular, afetam principalmente os anfibolitos e as rochas metabásicas, sendo em parte atribuídas à intrusão do corpo granítico. Datações geocronológicas U-Pb em 
zircão do granito Pojuca acusaram uma idade de $1.874 \pm 2 \mathrm{Ma}$, que foi interpretada como a de sua cristalização (Machado et al. 1991). Diques de diabásio, leve a moderadamente hidrotermalizados e de idade ainda desconhecida, ocorrem na área.

Os sulfetos hospedados no Grupo Igarapé Pojuca apresentam sinais de remobilização provocada pela intrusão granítica. A cúpula do granito Pojuca mostra-se, em decorrência, mineralizada, mas os teores de sulfetos diminuem fortemente com a profundidade, em claro testemunho de que a mineralização se restringe às zonas apicais, onde as fraturas permitiram acesso mais direto às soluções que haviam desestabilizado minerais de sulfetos contidos nas rochas encaixantes.

Características Petrográficas Gerais Duas variedades petrográficas principais foram identificadas no granito Pojuca. Uma delas, de caráter leucocrático, tem coloração rósea a cinza-rósea, textura dominantemente inequigranular, granulação média $(0,15$ a 2 $\mathrm{mm}$ ) e teor de fases máficas inferior a $5 \%$, tendo sido descrita nos testemunhos dos furos executados nos Corpos 1, 2 e 3 . A outra, hololeucocrática, é branco-amarelada, de textura idiomórfica a hipidiomórfica, mais ou menos equigranular, de granulação média, e com teor de minerais máfícos inferior a $1 \%$, tendo sido observada nos testemunhos de sondagem obtidos no Corpo 4. Ambas essas variedades apresentam domínios de aspecto pegmatóide. A textura gráfica não é incomum e ocorre sobretudo nas amostras da fácies leucocrática. Por outro lado, os indícios de greisenização são bem mais comuns nos tipos hololeucocráticos.

As rochas graníticas estão invariável mas levemente alteradas, de forma que ainda é possível reconstituir com bom grau de aproximação a composição mineralógica primária e estimar as composições modais médias das fácies leucocrática (quartzo $=37,9 \%$; feldspato potássico $=33,3 \%$; plagioclásio $=20,4 \%$ e outros $=8,4 \%$ ) e hololeucocrática (quartzo $=34,6 \%$; plagioclásio $=37,8 \%$; feldspato potássico $=21,7 \%$ e outros $=5,9 \%$ ). No grupo dos outros minerais estão incluídas não só as fases primárias varietais e acessórias, como também as secundárias.

O plagioclásio é uma albita, com teores de anortita raramente superiores a 4,5\% pelos critérios de Streckeisen (1976), as rochas podem ser, de modo geral, classificadas como álcali-feldspato granitos. Localmente há claras evidências de descalcificação do plagioclásio pelos fluidos hidrotermais, em decorrência de que alguns cristais são substituídos parcialmente por epídoto, fluorita e outros minerais. Para Horbe (1998), o plagioclásio primário deve ter sido mais cálcico, correspondendo à variedade oligoclásio, tanto que registra sieno e monzogranitos como as fácies petrográficas dominantes do granito Pojuca.

Composição Mineralógica As amostras estudadas foram, por força da metodologia, escolhidas dentre aquelas mais hidrotermalizadas, nas quais, no entanto, só excepcionalmente os produtos da alteração constituem mais de $10 \%$ do volume do corpo granítico. Em alguns casos, a separação entre minerais primários e secundários, apresentada a seguir, é arbitrária, pois existe, na evolução de uma magma, um continuam entre a cristalização a partir da fusão silicática e dos fluidos dela exsolvidos, os quais normalmente causam transformações pneumatolíticas e hidrotermais nas rochas já formadas. Com relação ao granito Pojuca, essa ambiguidade manifesta-se particularmente com o topázio, fluorita e turmalina, os quais, por conveniência descritiva, foram todos arrolados na categoria secundária.

MINERAIS PRIMÁRIOS Quartzo, feldspato potássico e plagioclásio são os minerais essenciais na composição do granito Pojuca. Biotita é a principal fase máfica, vindo a seguir o anfibólio (hornblenda hastingsítica ?), o qual pode ser observado ocasionalmente em amostras menos alteradas. A biotita está razoavelmente intacta em poucas amostras. No mais das vezes, está alterada para clorita e outros produtos, e sua identificação tornou-se possível graças à preservação da textura "casca de laranja" em cristais cloritizados e à própria associação secundária dela derivada. A alanita é o mineral varietal mais importante, enquanto zircão, apatita, policrásio, torita, uranotorita e ilmenita representam a suíte de fases acessórias.

Plagioclásio É o mineral dominante nas rochas do granito Pojuca, embora seja, em bem poucas amostras, menos abundante que o feldspato potássico ou o quartzo. E do tipo albita, com teores de anortita muito baixos, conforme dados ópticos e confirmação posterior via microssonda eletrônica. Os cristais de plagioclásio são anédricos a subédricos, de tamanhos variados, micromilimétricos a milimétricos, com predomínio do intervalo entre 0,4 a $0,8 \mathrm{~mm}$. Na fácies hololeucocrática eles tendem a ser menores e a desenvolver contornos mais euédricos. As formas mais comuns são as tabulares ou em ripas, que mostram geminação segundo as leis da albita, albita-periclina e Carlsbad. Só raramente estão essas macias encurvadas ou deslocadas por microfalhas. Com certa frequência, observa-se albita, sem macias, circundando ou substituindo grãos de feldspato potássico, sugerindo processo de albitização de estágio tardi-magmático, o que é confirmado pela presença de veios centimétricos de albita grossa (até cerca de $1 \mathrm{~cm}$ na maior dimensão) cortando as rochas graníticas. Outras vezes notam-se inclusões de quartzo, arredondadas a amebóides ou mesmo irregulares, dentro do plagioclásio, ocasionalmente tão abundantes que configuram uma textura poiquilítica. Outra forma de ocorrência de albita primária é como lamelas de exsolução, micrométricas a milimétricas, nas pertitas. Os cristais de plagioclásio, a despeito da alteração para mica branca, clorita, epídoto, fluorita e calcita, mantiveram-se, via de regra, límpidos e em grande parte intactos.

Feldspato Potássico Ocorre, em geral, em, quantidades inferiores às do plagioclásio e até mesmo do quartzo. É provavelmente microclina, se bem que nem sempre a textura em grade esteja evidenciada. Os intercrescimentos pertíticos são muito comuns, sobretudo as variedades em filete (string) e em manchas (patch), algumas vezes mais bem visíveis nas extremidades dos "cristais. A geminação de Carlsbad é também comum, mas os sinais de mirmequitização são ocasionais. Os cristais são essencialmente xenomórficos, porém formas subédricas podem ser observadas. As dimensões são variadas, indo de milimétrica a centimétrica, com maior frequência no intervalo de 0,8 a 1,5mm. Inclusões de quartzo, arredondadas a poligonais, de plagioclásio, subédricas e euédricas, e mesmo de feldspato potássico são frequentes, em especial as duas primeiras, emprestando a alguns cristais do feldspato potássico um arranjo poiquilitico. Mica branca, clorita, epídoto, calcita, quartzo e argilo-minerais são os principais produtos de alteração hidrotermal desse feldspato que, às vezes, ficam restritos às bordas dos grãos.

Quartzo As proporções de quartzo são, em geral, superiores às dos feldspatos, particularmente da microclina. Constatam-se pelo menos três diferentes modos de ocorrência de quartzo: 1) cristais isolados com dimensões entre 1 e $5 \mathrm{~mm}$; 2) grãos em agregados intergranulares com dimensões variando de 0,2 a 1,2mm; e 3 ) inclusões subarredondadas a poligonais com diâmetros entre $0,5 \mathrm{um}$ e $0,4 \mathrm{~mm}$, observadas sobretudo nos feldspatos. Predominam, de longe, os grãos xenomórficos, contudo certos cristais isolados ensaiam formas subédricas ou mesmo pseudo-hexagonais. Alguns cristais mostram leve extinção ondulante, enquanto outros acham-se bastante microfraturados. Embora não seja comum, observa-se substituição hidrotermal por mica branca, clorita ou calcita. Outras vezes são fortes os sinais de hematitízação.

Biotita Em poucas amostras a biotita está suficientemente preservada a ponto de poder ser diretamente identificada. Na maioria, restam apenas pseudomorfos compostos de clorita, feldspato potássico, titanita e óxidos de ferro. Os cristais ocorrem em palhetas subédricas, isoladas ou em agregados, dispersos pela rocha, com dimensões variadas que raramente ultrapassam $2 \mathrm{~mm}$. Estima-se que as quantidades originais de biotita atingiram, no máximo, $5 \%$ do volume das rochas.

Anfibólio Trata-se possivelmente de hornblenda hastingsítica, tendo sido observada em um número reduzido de amostras da fácies leucocrática. Ocorre em cristais essencialmente anédricos, com formas bastante irregulares e tamanhos variados, a maioria dentro da faixa de $0,15 \mathrm{a} 1,1 \mathrm{~mm}$. E comum formarem agregados que se interligam e chegam a desenvolver cordões estreitos com comprimento de até $2 \mathrm{~cm}$. Alguns cristais estão parcialmente substituídos por epídoto, clorita e fases opacas.

Alanita É mais frequente nas rochas da fácies leucocrática do que na hololeucocrática, no entanto, como mineral varietal, não está presente em todas as amostras estudadas. Os cristais são tabulares, subédricos a euédricos e de dimensões milimétricas, apresentando diferentes graus de metamictização que, quando moderada a intensa, torna suas terminações irregulares e marcadas pela precipitação de fases opacas de complexa composição. Essa precipitação, às vezes, estende-se por quase toda a superficie dos cristais, enegrecendo-os. E comum a pistacita circundar parcial ou completamente cristais de alanita, em processo de substituição ou de sobrecrescimento. Outras vezes é a titanita que se associa à alanita, parecendo substituí-la.

Zircão, apatita, torita/uranotorita, microlita, policrásio e ilmenita Essas fases acessórias, listadas tentativamente na ordem de abundância e frequência, ocorrem em cristais isolados e dispersos pela rocha, os quatro últimos tendo sido constatados em apenas algumas amostras. 
Em geral formam cristais subédricos a euédricos de tamanhos variados. A metamictização está presente em cristais de torita/uranotorita, policrásio e zircão, observando-se ainda nesse último grãos com sobrecrescimento ou sinais de hematitização. A microlita, em particular, foi encontrada numa fração pegmatóide dentro do anfibolito encaixante, bem no contato com o corpo granítico.

MINERAIS SECUNDÁRIOS Esses constituintes ocorrem em vênulas ou substituem a associação primária, sobressaindo dentre eles minerais raros que contêm apreciáveis quantidades de ítrio e de elementos terras raras em sua estrutura, ou mesmo de tório e/ou urânio. São descritos inicialmente os minerais que caracterizam o estágio pneumatolítico-hidrotermal, de mais alta temperatura, e, em seguida, aqueles tipicamente hidrotermais que se estabilizaram a temperaturas progressivamente mais baixas.

Topázio As observações indicam ser um dos minerais produzidos durante o estágio magmático-pneumatolítico, mas não se pode descartar sua geração também nos estágios subsequentes da alteração. Os cristais são subédricos a anédricos com dimensões que variam, em geral, de 0,4 a $2,5 \mathrm{~mm}$. Com os feldspatos, mostram, na maioria das vezes, contatos bastante irregulares a lobulados, porém também notam-se contatos retos. Outras vezes ocupam posições intersticiais ou substituem parcialmente grãos de plagioclásio, concentrando-se nas bordas ou adentrando até os núcleos. De outra feita, cristais de topázio apresentam-se substituídos por mica branca, que desenvolve franjas finas ao redor deles ou preenche microfraturas que os atravessam.

Fluorita A precipitação de fluorita deve ter iniciado também na fase pneumatolítica junto com o topázio e/ou turmalina. Esses cristais precoces são xenomórfieos, ocupam espaços intergranulares e mostram inclusões de diversos minerais acessórios primários. No estágio estritamente hidrotermal, chega a desenvolver formas euédricas e é bem mais abundante, ocorrendo em cristais grandes (até $6 \times 7$ $\mathrm{mm}$ ) e pequenos dispersos pela rocha em substituição ao plagioclásio e em vênulas em coexistência com calcita, clorita, mica branca, epídoto, quartzo ou sulfetos. Muitos cristais de fluorita acham-se, por seu turno, cortados por microvênulas de calcita, calcita + epídoto \pm hematita ou hematita.

Turmalina Não figura dentre os minerais mais comuns, porém é verificada em pelo menos $25 \%$ das amostras estudadas. Em geral, é mais abundante naquelas em que topázio e fluorita também estão presentes, sugerindo a precipitação a partir de um mesmo fluido rico em voláteis. Encontra-se em cristais pequenos $(<1 \mathrm{~mm})$ e anédricos dispersos pela rocha, mas nas vênulas forma cristais prismáticos maiores associados ao epídoto, quartzo, mica branca, fluorita e sulfetos. Nas paredes dessas vênulas a turmalina pode ser muito abundante e substituir os feldspatos e o próprio quartzo. Em bolsões pegmatóides, identificados no contato entre o granito e rochas anfibolíticas encaixantes, a turmalina destaca-se em cristais com até $1 \mathrm{~cm}$ de comprimento ao lado da bavenita, mica branca e calcita.

Bavenita Foi detectada em apenas uma amostra e ocorre em cristais prismáticos e fibrorradiais associada à turmalina, quartzo, mica branca e calcita.

No grupo dos minerais do estágio hidrotermal destacam-se, em tentativa ordem de abundância:

Quartzo Trata-se, certamente, do mais abundante mineral de alteração. Está presente em todas as vênulas, compondo várias associações, com exceção obviamente das vênulas monominerálicas formadas por outros minerais. As dimensões são micrométricas a milimétricas e as formas são variadas, desde aquelas bem desenvolvidas, pseudo-hexagonais, até as altamente disformes, estas últimas associadas à mica branca e clorita. Ocorre também em grãos esparsos ou substitui minerais preexistentes.

Clorita É encontrada, com diferentes teores, em todas as amostras estudadas e é, quantitativamente, em seguida ao quartzo, o mais importante produto da alteração hidrotermal do sistema Pojuca. Ocorre em cristais diminutos derivados da substituição da biotita e dos feldspatos, particularmente o plagioclásio, alanita e sulfetos, bem como em vênulas, monominerálicas ou não, e em agregados de grãos micrométricos junto à albita, epídoto e quartzo ou à mica branca.

Mica Branca Em geral é fina, mas às vezes desenvolve placas de verdadeira moscovita, sendo mais abundante na fácies hololeucocrática. A substituição, em diferentes graus, de feldspatos, em especial o plagioclásio, é o modo de ocorrência mais comum, com as palhetas micáceas distribuindo-se aleatoriamente, mas, muitas vezes, concentrando-se ao longo dos planos de macia. Outro modo a destacar é em placas de formas e tamanhos variados, associadas ao quartzo e epídoto, ou em agregados radiais em espaços intergranulares ocupados previamente por minerais primários. Nas vênulas a mica branca forma os maiores cristais, com até $1 \mathrm{~mm}$ de comprimento, comumente em agregados radiais, tipo leque, compondo com outras fases diferentes associações mineralógicas. Registram-se, também, vênulas monominerálicas dessa mica.

epídoto É um dos minerais hidrotermais mais abundantes, tendo sido observado em quase todas as amostras estudadas. Substitui parcialmente o plagioclásio (mais frequente), o feldspato potássico, as fases máficas e mesmo o quartzo, e, em torno da alanita, desenvolve verdadeiros sobrecrescimentos com bordas subédricas. E nas vênulas, contudo, que está presente em maiores quantidades associado à clorita, quartzo, sericita, calcita, turmalina, fluorita ou sulfetos.

Calcita É um dos produtos hidrotermais mais comuns nas rochas do granito Pojuca. Ocorre em substituição a cristais de plagioclásio, feldspato potássico, biotita e até mesmo quartzo, em agregados junto com clorita, quartzo, fluorita e sulfetos, e nos espaços intersticiais entre grãos de quartzo. Outra forma frequente de ocorrência é em vênulas monominerálicas ou associada a quartzo, fluorita, clorita, mica branca e epídoto.

Titanita É um dos minerais secundários mais comuns e o mais notável modo de ocorrência é como produto da alteracão de fases máficas, em especial da biotita, em associação com clorita, feldspato potássico, óxidos de ferro e, subordinadamente, epídoto. A titanita é igualmente encontrada em cristais xenomórfieos nos domínios onde a metamictização foi intensa, junto à alanita, zircão e a cristais da própria titanita provavelmente primários.

Feldspato Potássico $\mathrm{O}$ feldspato potássico secundário também não está presente em quantidades expressivas, ainda que seja mais frequente que a albita. Ocorre em vênulas, junto a outros minerais, em grãos dispersos pela rocha ou, mais localizadamente, como produtos da alteração de minerais máficos preexistentes. A ocorrência mais marcante é em bastonetes, em geral ao longo de planos de clivagem, que, ao lado da clorita e titanita, resultam da decomposição da biotita. Nas vênulas, as formas diminutas anédricas são as mais comuns, formas essas que, pontualmente, também estão presentes na massa granítica associadas a outros minerais de alteração.

Sulfetos Dentre os sulfetos, estão presentes calcopirita, que é dominante, e pirita. Além delas, constata-se também molibdenita, mas em quantidades bem subordinadas. Esses minerais ocorrem como disseminações pelas rochas ou, de forma mais concentrada, em vênulas juntos a vários outros constituintes.

Os minerais que se seguem são subordinados, embora em algumas amostras possam ser encontrados em apreciáveis quantidades:

Albita Como fase hidrotermal, a albita é bem pouco abundante, mas está presente em microvênulas sozinha ou associada a outros minerais, em grãos subédricos de 0,1 a $0,4 \mathrm{~mm}$. Ocorre também em agregados, junto à clorita e óxidos de ferro, ou em cristais pontualmente dispersos em domínios com maior grau de alteração, às vezes sob a forma de diminutos prismas alongados.

Stilpnomelana Foi observada em apenas duas amostras, em uma das quais $(\mathrm{F} 17 / 258,5=\mathrm{NV}-10)$ sobressai pela abundância. Além da discreta substituição de cristais de plagioclásio, ocorre sobretudo em vênulas formando agregados de pequenas palhetas, alguns de aspecto plumáceo. Nessas vênulas a associação mineral típica é calcita + quartzo + Stilpnomelana \pm alanita.

Minerais de Y e TR Como integrantes desse grupo de minerais foram identificados a gadolinita, a sinchisita e a hellandita. A gadolinita está representada por cerca de um dezena de diminutos cristais pseudohexagonais a subarredondados compondo a associação mineralógica de um veio junto à calcita, quartzo, sericita e epídoto. A hellandita ocorre em vênulas em cristais subédricos de dimensões milimétricas associada a sulfetos, mica branca, fluorita, quartzo e calcita. Fora das vênulas substitui discretamente cristais de plagioclásio e, às vezes, figura como produto da metamictização de cristais de alanita. Já a sinchisita foi observada em um agregado de pequenos cristais ocupando espaço intergranular entre quartzo e fase máfica bastante cloritizada e oxidada.

Óxidos de Fe elou Ti Desse grupo fazem parte a magnetita, a hematita, o rutilo (anatásio?) e a pirofanita. À exceção da hematita, 
nenhuma dessas fases se destaca quantitativamente, sendo representadas por grãos isolados ou por agregados que resultaram da alteração de minerais máfícos. A hematita, por outro lado, chega a ser o principal constituinte de algumas vênulas, nas quais ocorre em palhetas bem desenvolvidas associadas ao quartzo e clorita. De outra forma, aparece como películas ou manchas, que tingem vários minerais na rocha, ou preenche planos de microfissuras, em autêntico processo de hematitização, chegando a substituir parcialmente cristais de fluorita. Curiosa ocorrência é como cristais de saturação em inclusões fluidas presentes em quartzo hidrotermal.

Argilo-minerais Os argilo-minerais somente foram encontrados em três amostras, todas da fácies leucocrática e sempre em substituição a fases preexistentes. Eles pertencem ao grupo da esmectita e às variedades interestratificadas. Ocorrem em cristais finamente granulados, às vezes placóides, associando-se a outros produtos da alteração da biotita, em espaços intergranulares do quartzo e clorita, na forma de agregados juntos com minerais ricos em terras raras, ou podem ser derivados da metamictização de grãos de torita/uranotorita, concentrando-se em suas bordas.

Alanita Em uma única amostra constatou-se alanita como constituinte de um veio. Forma cristais diminutos, prismáticos, alguns encurvados, numa massa dominada por stilpnomelana, calcita e quartzo.

Composição Química dos Minerais As análises, em cerca de 20 lâminas delgadas, foram realizadas com auxílio de duas microssondas eletrônicas CAMECA, modelos CAMEBAX e SX-50, do consórcio CNRS-BRGM-Université d'Orléans, na França, que operaram com um potencial de $15 \mathrm{kVa}$ e corrente elétrica de $20 \mathrm{nA}$ usando padrões naturais e sintéticos. Foram determinados os teores dos elementos maiores e de alguns traços (ETR, U, Th, Y, Ta, Nb, Sn, Zr e F) nos silicatos e óxidos, enquanto nos sulfetos foram dosados $\mathrm{S}, \mathrm{Fe}$, $\mathrm{Cu}, \mathrm{Pb}, \mathrm{Zn}, \mathrm{As}, \mathrm{Bi}$ e $\mathrm{Au}$. Teores abaixo de $0,1 \%$ para certos elementos não têm mais do que valor semi-quantitativo.

Os dados químicos (média das análises pontuais em vários cristais de diferentes amostras de rocha) estão apresentados nas Tabelas 1 a 6.

PLAGIOCLÂSIO O plagioclásio primário é do tipo albita com variação composicional de $\mathrm{Ab}_{96,18-99.51} \mathrm{An}_{0,30-3,4} \mathrm{Or}_{0.19-50}$ para a fácies leucocrática e de $\mathrm{Ab}_{97,74990_{0}} \mathrm{An}_{0,22-1,63} \mathrm{Or}_{0,18-0,67}$ para a fácies hololeucocrática, com ampla superposição portanto, apesar de a primeira mostrar-se ligeiramente mais enriquecida na fração anortítica (Tab. 1; Fig. 3). Considerando que alguns cristais estão parcialmente alterados para epídoto, calcita e fluorita, os teores de anortita poderiam ter sido mais elevados e o que hoje se observa corresponder a plagioclásio modificado. Acontece que mesmo se todo o $\mathrm{Ca}$ contido naqueles produtos de alteração proviesse do plagioclásio, ainda assim a perda em termos de fração anortítica não ultrapassaria dois pontos percentuais. Além dessa estimativa, agregue-se o fato de coexistirem, lado a lado, numa mesma lâmina, cristais parcialmente substituídos e outros quase sem sinais de alteração, ambos com composição da albita.
Plagioclásio mais rico em anortita somente foi observado em amostras de porções pegmatóides. Na porção presente no próprio corpo granítico (fácies leucocrática) determinou-se para alguns cristais composição média de $\mathrm{Ab}_{89}{ }_{18} \mathrm{An}_{9}{ }_{96} \mathrm{Or}_{0}{ }_{86}$, enquanto naquela encontrada nos anfibolitos encaixántes, no contato com o granito, a composição média é de $\mathrm{Ab}_{84.23} \mathrm{An}_{13.79} \mathrm{Or}_{1.98}$. No entanto, esses cristais ocorrem juntos a outros com composição distinta, bem mais albítica, correspondendo a $\mathrm{Ab}_{97,74} \mathrm{An}_{1,71} \mathrm{Or}_{0,55}$ e a $\mathrm{Ab}_{96,84} \mathrm{An}_{2,56} \mathrm{Or}_{0,50}$, respectivamente. Igualmente ricas na fração albítica são algumas lamelas de exsolução no feldspato potássico que revelaram composição $\mathrm{Ab}_{98,70} \mathrm{An}_{0,84} \mathrm{Or}_{0,46}$.

Ainda mais rico na fração albítica é o plagioclásio hidrotermal (Tab. 1 e Fig. 3) que se aproxima muito da composição estequiométrica da albita com $\mathrm{Ab}_{9,19-99,68} \mathrm{An}_{0,15-0,50} \mathrm{Or}_{0,11-0,31}$

FELDSPATO POTÁSSICO As variedades primárias, tanto da fácies leucocrática como da hololeucocrática, são quimicamente bem homogéneas com teor máximo de $\mathrm{Na}_{2} \mathrm{O}$ de $0,46 \%$ e praticamente sem $\mathrm{Ca}$, correspondendo ao intervalo composicional $\mathrm{Or}_{95.84-98.29} \mathrm{Ab}_{0.46}$. ${ }_{41.10} \mathrm{An}_{0.00-0.32}$ (Tab. 1 e Fig. 3). As variedades secundárias, independentemente da derivação, são também homogéneas, à exceção de uma amostra (NV-02), que tem teor de $\mathrm{Na}_{2} \mathrm{O}$ seis a sete vezes maior que a média das demais. Desconsiderada esta amostra e comparativamente ao feldspato potássico primário, elas têm composição muito similar, na faixa de $\mathrm{Or}_{96.0898282} \mathrm{Ab}_{1,72-3.02} \mathrm{An}_{0.00090} \mathrm{em}$ média, pelo menos 12 vezes mais ricas em FeO (Tab. 1 e Fig. 4).

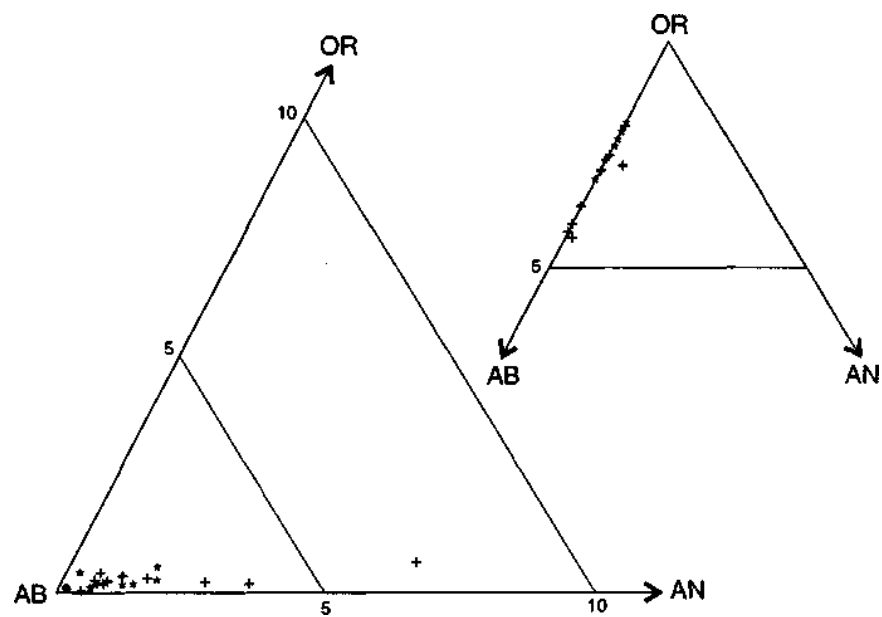

Figura 3 - Composição do plagioclásio e do feldpato potássico de rochas das fácies leucocrática (+) e hololeucocrática (*) em termos das $f$ rações molares de ortoclásio $(O R)$, albita $(A B)$ e anortita $(A N)$. $O$ círculo cheio $(\bullet)$ representa albita presente em vênula hidrotermal.

Tabela l-Composição química (\% em peso) dos feldspatos primário e secundário do granito Pojuca, Serra dos Carajás (PA). Ab, An e Or correspondem, respectivamente, às proporções moleculares de albita, anortita e ortoclásio. O número entre parênteses representa o número de análises pontuais; $n d=$ não determinado; $t r=$ quantidades traços; - = abaixo do limite de detecção; var. comp. = variação composicional

\begin{tabular}{|c|c|c|c|c|c|c|c|c|c|c|c|c|c|}
\hline & \multicolumn{6}{|c|}{ PLAGIOCLÄSIO } & \multicolumn{7}{|c|}{ FELDSPATO POTASSICO } \\
\hline & \multirow{2}{*}{\multicolumn{2}{|c|}{$\begin{array}{c}\text { Fúcies } \\
\text { Leucocrática }\end{array}$}} & \multirow{2}{*}{\multicolumn{2}{|c|}{$\begin{array}{c}\text { Fácies } \\
\text { Hololeucocrática }\end{array}$}} & \multirow{2}{*}{\multicolumn{2}{|c|}{$\begin{array}{c}\text { Hidrotermal } \\
\text { Veio }\end{array}$}} & \multirow{2}{*}{\multicolumn{2}{|c|}{$\begin{array}{c}\text { Fácies } \\
\text { Leucocrática }\end{array}$}} & \multirow{2}{*}{\multicolumn{2}{|c|}{$\begin{array}{c}\text { Fácies } \\
\text { Hololeucocrática }\end{array}$}} & \multicolumn{3}{|c|}{ Hidrotermal } \\
\hline & & & & & & & & & & & \multicolumn{2}{|c|}{ Alteracảo da biotita } & \multirow{2}{*}{$\begin{array}{c}\text { Veio } \\
\text { média } \\
\text { (4) }\end{array}$} \\
\hline & $\begin{array}{c}\text { média } \\
(99)\end{array}$ & var. comp. & $\begin{array}{c}\text { média } \\
(67)\end{array}$ & var. comp. & $\begin{array}{c}\text { media } \\
(7)\end{array}$ & var. comp. & $\begin{array}{c}\text { média } \\
(65)\end{array}$ & var. comp. & $\begin{array}{l}\text { média } \\
(42)\end{array}$ & var. comp. & $\begin{array}{c}\text { média } \\
(25)\end{array}$ & var. comp. & \\
\hline $\mathrm{SiO}_{2}$ & 67,08 & $64,88-68,30$ & 67,75 & $63,98-69,21$ & 68,19 & $67,01-69,40$ & 63,53 & $61,52-64,86$ & 65,16 & $63,92-66,50$ & 63,37 & $62,43-64,75$ & 63,59 \\
\hline $\mathrm{TiO}_{2}$ & 0,01 & $0,00-0,02$ & 0,01 & $0,00-0,04$ & 0,00 & - & $<0,01$ & $0,00-0,02$ & $.0,01$ & $0,00-0,01$ & 0,01 & $0,00-0,02$ & 0,00 \\
\hline $\mathrm{Al}_{2} \mathrm{O}_{3}$ & 19,95 & $19,10-20,86$ & 19,92 & $19,01-22,20$ & 19.97 & $19,60-20,32$ & 18,14 & $17,65-18,50$ & 18,32 & $18,01-18,70$ & 18,06 & $17,87-18,53$ & 17,18 \\
\hline $\mathrm{FeO}_{4}$ & 0,07 & $0,00-0,16$ & 0,05 & $0,01-0,22$ & 0,15 & $0,00-0,39$ & 0,08 & $0,02-0,24$ & 0,02 & $0,01-0,04$ & 0,77 & $0,31-2,13$ & 0,33 \\
\hline $\mathrm{MnO}$ & 0,01 & $0,00-0,04$ & 0,02 & $0,01-0,04$ & 0,02 & $0,00-0,06$ & 0,01 & $0,00-0,03$ & 0,01 & $0,00-0,03$ & 0,02 & $0,01-0,03$ & 0,03 \\
\hline $\mathrm{MgO}$ & 0,01 & $0,00-0,03$ & $<0,01$ & - & 0,01 & $0,00-0,03$ & $<0,01$ & $0,00-0,01$ & $<0,01$ & $0,00-0,01$ & 0,01 & $0,00-0,05$ & Ir \\
\hline $\mathrm{CaO}$ & 0,43 & $0,06-2,09$ & 0,54 & $0,04-2,88$ & 0,06 & $0,03-0,11$ & 0,01 & $0,00-0,06$ & 0,01 & $0,00-0,06$ & 0,05 & $0,00-0,18$ & 0,09 \\
\hline $\mathrm{Na}_{2} \mathrm{O}$ & 11,16 & $10,32-11,74$ & 11,54 & $9,70-12,29$ & 11,07 & $10,72-11,45$ & 0,30 & $0,19-0,46$ & 0,28 & $0,23-0,34$ & 0,48 & $0,19-1,70$ & 0,27 \\
\hline $\mathrm{K}_{2} \mathrm{O}$ & 0,08 & $0,02-0,25$ & 0,10 & $0,03-0,35$ & 0,03 & $0,02-0,05$ & 16,06 & $15,05-16,83$ & 16,12 & $15,61-16,70$ & 15,88 & $14,46-16,74$ & 16,29 \\
\hline $\mathrm{La}_{2} \mathrm{O}_{3}$ & 0,05 & $0,00-0,12$ & 0,04 & $0,00-0,14$ & 0,02 & - & 0,05 & $0,00-0,09$ & 0,04 & $0,00-0,12$ & 0,05 & $0,01-0,12$ & 0,00 \\
\hline $\mathrm{Ce}_{2} \mathrm{O}_{3}$ & 0,05 & $0,00-0,13$ & 0,07 & $0,00-0,19$ & 0,03 & $0,00-0,09$ & 0,05 & $0,00-0,12$ & 0,04 & $0,00-0,14$ & 0,04 & $0,00-0,15$ & 0,03 \\
\hline $\mathrm{Y}_{2} \mathrm{O}_{3}$ & 0,03 & $0,00-0,13$ & $<0,01$ & - & 0,10 & $0,00-0,20$ & 0,05 & $0,02-0,11$ & 0,00 & $=$ & 0,02 & $0,00-0,07$ & nd \\
\hline $\mathrm{UO}_{2}$ & 0,03 & $0,00-0,06$ & 0,02 & $0,00-0,12$ & 0,06 & $0,04-0,09$ & 0,04 & $0,00-0,14$ & 0,03 & $0,03-0,04$ & 0,03 & $0,00-0,04$ & nd \\
\hline ThO, & 0,03 & $0,00-0,07$ & 0,03 & $0,0040,07$ & 0,05 & $0,00-0,10$ & 0,04 & $0,00-0,10$ & 0,03 & $0,00-0,11$ & 0,06 & $0,00-0,12$ & nd \\
\hline Total & 98,99 & $98,22-99,66$ & 100,09 & $97,46-101,34$ & 99,68 & $98,78-101,22$ & 98,36 & $96,10-99,72$ & 100,04 & $99,30-101,45$ & 98,85 & $97,46-99,77$ & 97,81 \\
\hline $\mathbf{A b}$ & 97,49 & $89,18-99,16$ & 98,58 & $96,94-99,30$ & 99,45 & $99,19-99,68$ & 2,78 & $1,71-4,10$ & 2,63 & $2,05-3,06$ & 4,21 & $1,72-14,52$ & 2,49 \\
\hline $\mathrm{An}$ & 2,08 & $0,30-9,96$ & 1,00 & $0,22-2,56$ & 0,35 & $0,15-0,50$ & 0.11 & $0,00-0,32$ & 0,02 & $0,00-0,06$ & 0.15 & $0,00-0,90$ & 0,46 \\
\hline Or & 0,43 & $0,19-0,86$ & 0,42 & $0,18-0,67$ & 0,20 & $0,11-0,31$ & 97,11 & $95,84-98.29$ & 97,35 & $96,89-97,95$ & 95,64 & $85,47-98,28$ & 97,04 \\
\hline
\end{tabular}




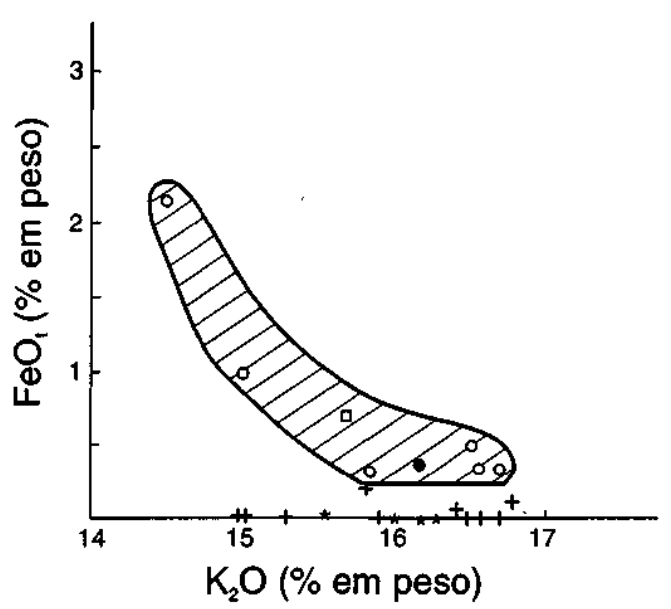

Figura 4 - Diagrama FeOt $x \mathrm{~K}_{2} \mathrm{O}$ comparando a distribuição dos feldspatos potássicos primários e hidrotermais (área hachurada), estes bem mais ricas em $\mathrm{Fe} .(+)=$ fácies leucocratica; $(*)=$ fácies hololeucocrática; $(o)$ = produto da alteração da biotita; $(\bullet)=\mathrm{em}$ vênula; () = em forma de espícula.

ALANITA As alanitas ígnea e hidrotermal mostram ampla variação composicional em termos de $\mathrm{FeO}_{\mathrm{t}}, \mathrm{Al}_{2} \mathrm{O}_{3}$ e $\left(\mathrm{La}_{2} \mathrm{O}_{3}+\mathrm{Ce}_{2} \mathrm{O}_{3}\right)$, com diferenças entre os valores máximo e mínimo de cada um desses componentes em torno de $10 \%$ (Tab. 2). Os outros componentes maiores, $\mathrm{SiO}_{2}$ e $\mathrm{CaO}$, registram variações mais estreitas com diferenças que raramente passam de quatro pontos percentuais. A heterogeneidade é também verificada nos componentes menores, a exemplo do $\mathrm{TiO}_{2}, \mathrm{MnO}, \mathrm{Y}_{2} \mathrm{O}_{3}$ e $\mathrm{ThO}_{2}$ com diferenças de até $1,4 \%$. As razões $\mathrm{Ce}_{2} \mathrm{O}_{3} / \mathrm{La}_{2} \mathrm{O}_{3}$ variam de 2,19 a 4,13 com média de 2,82 . Outros elementos terras raras foram determinados em quatro amostras, duas de cada daqueles tipos, fornecendo valores totais de $\mathrm{TR}_{2} \mathrm{O}_{3}$ de 17,78 a $30,01 \%$, com destaque para as concentrações relativamente altas de $\mathrm{Pr}, \mathrm{Nd}$ e $\mathrm{Gd}$, além obviamente de $\mathrm{La}$ e Ce. A primeira vista, a metamictização poderia ser em parte responsável por essa falta de uniformidade composicional, mas mesmo nas amostras em que esse processo não é tão evidente, a heterogeneidade se manifesta, sugerindo peculiaridades do microambiente químico em que a alanita cristalizou ou populações formadas em diferentes estágios da cristalização magmática.

TITANITA Do ponto de vista químico (Tab. 2), a maior diferença entre as titanitas ígnea e hidrotermal está nos teores de $\mathrm{Al}_{2} \mathrm{O}_{3}$, que são mais elevados no último tipo por fatores que vão de 2,1 a 4,7 . Os teores de $\mathrm{FeO}_{\mathrm{t}}$ também tendem a ser mais altos na titanita hidrotermal, com fatores de enriquecimento entre 1,2 e 4,7, embora 1/3 das amostras seja mais empobrecida. Dessa maior entrada de $\mathrm{Al}$ e $\mathrm{Fe}$ na estrutura da titanita hidrotermal, decorrem teores de $\mathrm{TiO}_{2}$ relativamente mais baixos, com média de $28,13 \%$, que está pouco mais de sete pontos percentuais abaixo do valor de $35,34 \%$ determinado para a titanita ígnea. Registram-se, também, concentracões mais altas de $\mathrm{Y}_{2} \mathrm{O}_{3}$ (cerca de 4 vezes) e mais baixas de $\mathrm{F}$ (cerca de 5 vezes) da titanita ígnea do que na correspondente hidrotermal. Com respeito apenas às variedades secundárias, as que ocorrem em veios se mostram, em geral, menos ricas em $\mathrm{Al}_{2} \mathrm{O}_{3}$ e em $\mathrm{FeO}$ do que as resultantes da alteração da biotita e, em decorrência, são mais enriquecidas em $\mathrm{TiO}_{2}$.

CLORITA As análises químicas (Tab. 3) mostram que a clorita do granito Pojuca pode ser classificada como chamosita (Bayley 1988). Com base no diagrama $\mathrm{FeO}_{\mathrm{t}} \times \mathrm{MgO}$ (Fig. 5), foram distinguidas populações menos e mais magnesianas com linha divisória correspondendo ao teor de $\mathrm{MgO}$ igual a $4 \%$, populações essas que foram respectivamente designadas de Fe-chamositas e Mg-chamositas. Como mineral de substituição, as Fe-chamositas derivam do plagioclásio, biotita e sulfetos, enquanto as Mg-chamositas derivam do feldspato potássico, biotita e alanita.

Em termos dos componentes principais $\mathrm{SiO}_{2}, \mathrm{Al}_{2} \mathrm{O}_{3}, \mathrm{FeO}_{\mathrm{t}}$ e $\mathrm{MgO}$, as Fe-chamositas são, de modo geral, relativamente mais homogéneas do que as Mg-chamositas. O mais alto teor de $\mathrm{SiO} 2(32,99 \%)$ e o menor de $\mathrm{Al}_{2} \mathrm{O}_{3}(16 \%)$ foram observados na amostra NV-03B, cuja clorita se encontra intimamente associada à alanita em contato com biotita transformada ou em agregados de granulação fina junto ao epídoto.
Tabela 2 - Composição química (\% em peso) da alanita e titanita presente no granito Pojuca, Serra dos Carajás (PA). TR2Ü3 = outras terras raras; fy $O^{*}=$ água molecular calculada. Mesma legenda da tabela 1 .

\begin{tabular}{|c|c|c|c|c|c|c|c|}
\hline & \multicolumn{4}{|c|}{ ALANITA } & \multicolumn{3}{|c|}{ TITANITA } \\
\hline & \multicolumn{2}{|r|}{ \{GNEA } & \multicolumn{2}{|c|}{ HIDROTERMAL } & IGNEA & \multicolumn{2}{|c|}{ HIDROTERMAL } \\
\hline & $\begin{array}{l}\text { média } \\
\text { (7I) }\end{array}$ & var. comp. & $\begin{array}{l}\text { média } \\
(19)\end{array}$ & var. comp. & $\begin{array}{c}\text { média } \\
\text { (16) }\end{array}$ & $\begin{array}{c}\text { média } \\
(47)\end{array}$ & var. comp. \\
\hline $\mathrm{SiO}_{2}$ & 31,22 & $29,57 \cdot 34,85$ & 32,26 & $31,41 \cdot 33,54$ & 28,99 & 30,42 & $29,31-31,26$ \\
\hline $\mathrm{TiO}_{2}$ & 0,45 & $0,01-1,41$ & 0,41 & $0,01-1,12$ & 35,34 & 28,13 & $23,32-33,66$ \\
\hline $\mathrm{Al}_{2} \mathrm{O}_{3}$ & 15,54 & $12,17-21,97$ & 16,84 & $13,92-18,48$ & 2,03 & 6,78 & $4,24-9,47$ \\
\hline $\mathrm{FeO}_{1}$ & 13,15 & $8.91-17,78$ & 13,22 & $10,77 \cdot 16,27$ & 1,69 & 3,05 & $1,24-7,99$ \\
\hline $\mathrm{MnO}$ & 0,28 & $0,03-0,75$ & 0,18 & $<0,0 !-0,4 !$ & 0,03 & 0,14 & $0,01-0,61$ \\
\hline $\mathrm{MgO}$ & 0,08 & $0,01-0,09$ & 0,29 & $0,00-0,86$ & 0,12 & 0,23 & $0,00-1,03$ \\
\hline $\mathrm{CaO}$ & 11,09 & $9,68-13,66$ & 10,60 & $10,27-11,00$ & 26,49 & 26,18 & $23,32-28,40$ \\
\hline $\mathrm{SnO}$ & - & - & 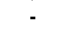 & - & 0,47 & 0,08 & $>0,01-0,10$ \\
\hline $\mathrm{Na}_{2} \mathrm{O}$ & 0,09 & $0,02-0,25$ & 0,03 & $0,01-0,07$ & 0,05 & 0,05 & $0,01-0,15$ \\
\hline $\mathrm{K}_{2} \mathrm{O}$ & 0,03 & $<0,01-0,07$ & 0,05 & $0,01+0,09$ & is & 0,08 & $0,01-0,40$ \\
\hline $\mathrm{La}_{2} \mathrm{O}_{3}$ & 4,33 & $2,63-6,37$ & 4,18 & $2,89-5,59$ & 0,07 & 0,05 & $>0,01-0,14$ \\
\hline $\mathrm{Ce}_{2} \mathrm{O}_{3}$ & 11,60 & $7,34-15,36$ & 11,13 & $9,15-13,77$ & 0,15 & 0,05 & $>0,01-0,12$ \\
\hline $\mathrm{TR}_{2} \mathrm{O}_{3}$ & 7,21 & $3,80-10,60$ & 8,19 & $4,65=10,48$ & - & - & - \\
\hline $\mathrm{Y}_{2} \mathrm{O}_{3}$ & 0,50 & $0,11-0,82$ & 0,32 & $0,21-0,43$ & 1,30 & 0,33 & $0,02-1,66$ \\
\hline $\mathrm{UO}_{2}$ & 0,04 & $<0,01-0,10$ & 0,03 & $<0,01-0,05$ & $\mathbf{t r}$ & 0.02 & $>0,01 \cdot 0,08$ \\
\hline $\mathrm{ThO}_{2}$ & 0,49 & $0,04-1,27$ & 0,20 & $0,06-0,48$ & ư & 0,05 & $>0,01-0,18$ \\
\hline $\mathbf{F}$ & nd & - & nd & - & 0,26 & 1,36 & $0,78-2,13$ \\
\hline$F=0$ & - & . & - & $=$ & $-0,11$ & $-0,57$ & $-(0,33-0,90)$ \\
\hline $\mathrm{H}_{2} \mathrm{O}^{*}$ & 1,47 & $1,39 \cdot 1,67$ & 1,43 & $1,23-1,57$ & - & - & . \\
\hline Total & 97,57 & $96,02-101,60$ & 99,36 & $93,13+102,38$ & 96,88 & 96,38 & $94,23-99,00$ \\
\hline
\end{tabular}

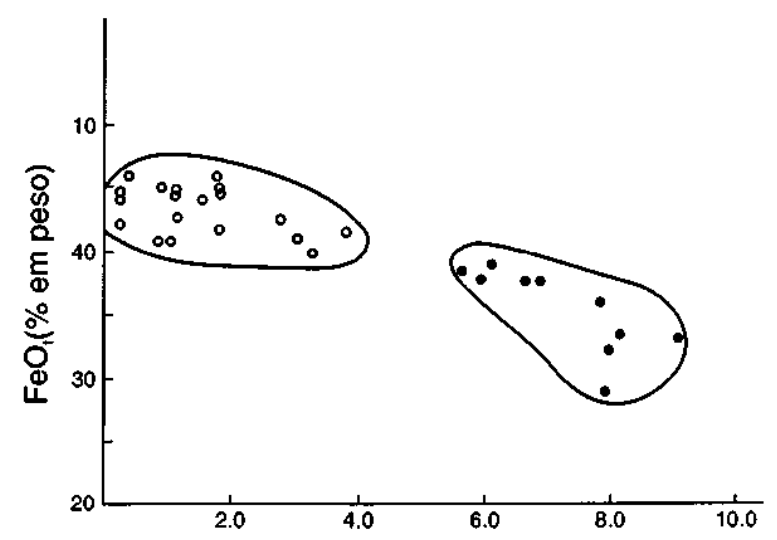

$\mathrm{MgO}(\%$ em peso)

Figura 5 - Diagrama FeOt x $\mathrm{MgO}$ mostrando a variação composicional das cloritas do granito Pojuca e a existência de duas distintas populações separadas por teores de $\mathrm{MgO}$ menores e maiores que 4\%. $o=F e$-chamositas $; \bullet=M g$-chamositas .

Daí, certamente, o elevado teor de $2,05 \%$ para o $\mathrm{CaO}$, que pode ser interpretado como contaminação.

Chama a atenção cloritas, em uma mesma amostra, derivadas de diferentes minerais e com praticamente a mesma composição química, mostrando que não foram eles, mas sim a composição dos fluidos, o controle decisivo do tipo de clorita estabilizado. De outra feita, coexistem, lado a lado, cloritas com composições bem distintas, as quais foram seguramente controladas bem mais pelo quimismo do mineral substituído. Essas observações permitem sugerir que as razões fluido/rocha foram determinantes na definição composicional das cloritas e certamente também de outras fases hidrotermais.

EPIDOTO Os dados químicos do epídoto (Tab. 3) indicam tratar-se de pistacita que mostra grande variação composicional, sobretudo quanto aos teores de $\mathrm{Al}_{2} \mathrm{O}_{3}$ e $\mathrm{Fe}_{2} \mathrm{O}_{3(\mathrm{t})}$ os quais apresentam comportamento antipatético. Essa variação e comum em sistemas geotermais antigos e modernos e é devida a diversos fatores que incluem temperatura, fugacidade de $\mathrm{O}_{2}$ e $\mathrm{CO}_{2}$, além da composição das soluções e dos minerais que foram alterados (Shikazono 1984). Em termos das frações molares de zoisita (Zo), pistacita (Ps) e piedmontita (Pd), apresentam composição $\mathrm{Z}_{0,044,4} \mathrm{PS}_{55,00-99.09} \mathrm{Pd}_{0,342,14}$ com menor dispersão verificada na pistacita que substitui ou envolve cristais de alanita.

FENGITA As fórmulas estruturais obtidas a partir dos dados químicos (Tab. 3) enquadram a mica branca do granito Pojuca na definição de fengita (Deer et al. 1966), haja vista apresentarem razões Si/Ál ${ }^{\mathrm{iv}}$ que variam de 3,14 a 4,80 para as menos silícicas e de 16,02 a 16,39 para as mais silícicas, todas portanto maiores que 3 (Fig. 6). Muitas 
Tabela 3 - Composição química (\% em peso) da cloríta, fengita e epídoto do granito Pojuca, Serra dos Carajás (PA). Mesma legenda da tabela 1.

\begin{tabular}{|c|c|c|c|c|c|c|c|c|}
\hline & \multicolumn{4}{|c|}{ CLORITA } & \multirow{2}{*}{\multicolumn{2}{|c|}{ FENGITA }} & \multirow{2}{*}{\multicolumn{2}{|c|}{ EPIDOTO }} \\
\hline & \multicolumn{2}{|c|}{ Fe-Chamosita } & \multicolumn{2}{|c|}{ Mg-Chamosita } & & & & \\
\hline & $\begin{array}{l}\text { חúdiala } \\
\text { (167) }\end{array}$ & var. comp. & $\begin{array}{c}\text { média } \\
\text { (72) }\end{array}$ & var. comp. & $\begin{array}{c}\text { módiala } \\
(97)\end{array}$ & vat. comp. & $\begin{array}{c}\text { média } \\
(87)\end{array}$ & var comp. \\
\hline $\mathrm{SiO}_{x}$ & 22.49 & $21,30-26,13$ & 25,72 & $23,33-32,99$ & 48.13 & $45,68-56,30$ & 37,19 & $36,18-38,99$ \\
\hline $\mathrm{TiO}_{2}$ & 0,04 & $<0,011-0,110$ & 0,02 & & & & & \\
\hline $\mathrm{Al}_{2} \mathrm{C}$ & {$[4,6]$} & $14,82-21,94$ & 19,52 & $16,00-20$ & 30,32 & $17,58-34,31$ & 23,14 & \\
\hline $\mathrm{Fe}_{2} \mathrm{O}_{301}$ & & 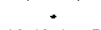 & - & - & & & 13,41 & $9,35-17,82$ \\
\hline FeO, & 43,39 & $39.40-46.17$ & 33,83 & $26,24-38,63$ & 3,99 & $1,61-8,90$ & & \\
\hline $\mathrm{Mn}_{2} \mathrm{C}$ & & & & & & & 0,16 & $0,05-0,35$ \\
\hline Mno & 0,58 & $0,29-1,11$ & $(0,54$ & $0,31-0,48$ & 0,04 & & & \\
\hline $\mathrm{MgO}$ & & & 7,56 & & & & 0,07 & \\
\hline $\mathrm{CaO}$ & 0,10 & $2-0,43$ & 0,32 & & & & 22,22 & 3,68 \\
\hline $\mathrm{Na}_{2} \mathrm{O}$ & & & 0.08 & & & & 0,04 & \\
\hline $\mathrm{K}_{2} \mathrm{O}$ & 0,09 & & 0,25 & & 10.79 & & 0.03 & \\
\hline $\mathrm{La}_{ \pm} \mathrm{O}_{\mathrm{k}}$ & & & 0. & & & & 0,97 & \\
\hline $\mathrm{Ce}_{2} \mathrm{O}_{3}$ & 0,04 & & 0,17 & & & & 0,17 & \\
\hline $\mathrm{Y}_{2} \mathrm{O}_{3}$ & 0,03 & & 0,05 & & 0,03 & & 0,18 & $-0,81$ \\
\hline $\mathrm{UO}_{2}$ & $(0,0)$ & & 0,04 & & & & 0,02 & $0,00-0,06$ \\
\hline $\mathrm{ThO}_{2}$ & 0,013 & & 0,07 & & & & 0,04 & $0,00-0,09$ \\
\hline & & & 10,76 & 10,49 & & & nd & \\
\hline Tolat & 48.15 & $96,26-49,41$ & 49,02 & $97,37-100,78$ & 98,63 & $94,53-100,42$ & 96.78 & $95,48-99,05$ \\
\hline
\end{tabular}

aproximam-se da composição ideal da moscovita e todas revelam a presença da fração paragonítica, a qual chega a ser expressiva em espécimens resultantes da alteração do plagioclásio.

Quimicamente a fengita mostra grande variação composicional, sobretudo em termos de $\mathrm{SiO}_{2}, \mathrm{~A}_{2} \mathrm{O}_{3}$ e $\mathrm{FeO}_{\mathrm{t}}$ com diferenças máximas de, respectivamente, $10,62 \%, 16,73 \%$ e $7,29 \%$. Essas diferenças são um pouco menores quando as micas brancas são agrupadas pelo modo de ocorrência, as menos heterogéneas sendo aquelas encontradas nos veios hidrotermais, caso em que cabe ao $\mathrm{FeO}_{\mathrm{t}}$, em valores relativos, a maior dispersão.

Os resultados analíticos e as associacões minerais sugerem que a composição da fengita foi influenciada tanto pelo quimismo das soluções hidrotermais quanto pelo mineral substituído e, certamente, também pela temperatura. E sintomático que nos veios sejam observadas micas com teores altos e baixos de Fe. É igualmente sintomático que fases ferromagnesianas (biotita) tenham gerado micas ricas em $\mathrm{Fe}$ e, em geral, também em $\mathrm{Mg}$, enquanto que fases félsicas (plagioclásio) tenham produzido micas pobres nesses elementos.

STILPNOMELANA A análise química de stilpnomelana (Tab. 4), na única amostra em que foi encontrada (NV-10), é comparável às que são fornecidas por Deer et al. (1962), as quais registram intervalos de $[42,42-48,03 \%]$ para $\mathrm{SiO}_{2},[4,35-7,59 \%]$ para $\mathrm{Al}_{2} \mathrm{O}_{3},[23,34-39,28 \%]$ para $\mathrm{FeO}_{\mathrm{t}}$ e $[0,57-2,06 \%]$ para $\mathrm{K}_{2} \mathrm{O}$. A rigor, a mais significativa variação composicional está nos teores de $\mathrm{FeO}$ e $\mathrm{Fe}_{2} \mathrm{O}_{3}$ que, para a stilpnomelana do granito Pojuca, foram estimados, por procedimento reconhecidamente vulnerável, em 1,8 e $35,8 \%$ respectivamente. $\mathrm{O}$ cálculo adotou a média da soma de $\mathrm{H}_{2} \mathrm{O}^{+}$e $\mathrm{H}_{2} \mathrm{O}-(9,18 \%)$ de doze análises de stilpnomelana de Deer et al. (1962) e o fechamento ideal da análise NV-10 em 100\%. Aquelas estimativas, mostrando a grande predominância do ferro férrico sobre o ferroso, são condizentes com a cor marrom escuro observada na stilpnomelana do granito Pojuca.

ARGILO-MINERAIS A falta de dados difratométricos impediu uma caracterização mais precisa dos argilo-minerais presentes nas associações hidrotermais do granito Pojuca. Não obstante essa limitação, eles foram tentativamente identificados a partir de análises químicas (Tab. 4) e de feições texturais observadas em lâminas delgadas como espécimens dos grupos da esmectita (montmorillonita e nontronita), da illita (illita?) e do tipo interestratificado (clorita-montmorillonita)

Os resultados analíticos para montmorillonita e nontronita são comparáveis aos existentes na literatura (Deer et al. 1966, Weaver \& Pollard 1973, Gabis 1979), sendo ambas dioctaédricas. A identificação da illita é menos confiável. Os dados analíticos não são inteiramente coincidentes com aqueles disponíveis na literatura (Deer et al. 1966 Weaver \& Pollard 1973, Gabis 1979), em particular no que concerne ao elevado teor de $\mathrm{Fe}^{+3}(12,83 \%)$, em substituição ao $\mathrm{Al}$, e ao baixo teor de $\mathrm{F}^{\wedge} \mathrm{O}$ que pode ser inferido com base no total de $99,18 \%$ obtido para os demais componentes. As características químicas combinam mais com a fengita, no entanto as proporções atómicas mostram razão $\mathrm{Si}^{\mathrm{iV}} / \mathrm{Al}^{\mathrm{IV}}<3,0$ e $\mathrm{K}^{+}<1,0$. É bem mais provável tratar-se de uma mistura de illita e fengita.

A variedade interestratifícada é, ao que tudo indica, do tipo cloritasmectita, haja vista o baixo teor de sílica $(31,2 \%)$ e altos teores de $\mathrm{Fe}_{2} \mathrm{O}_{3}$ total $(26,11 \%)$ e de $\mathrm{MgO}(6,42 \%)$.

MINERAIS RICOS EM ÍTRIO E TERRAS RARAS As características ópticas e, sobretudo, as análises químicas (Tab. 5) apontaram a ocor-

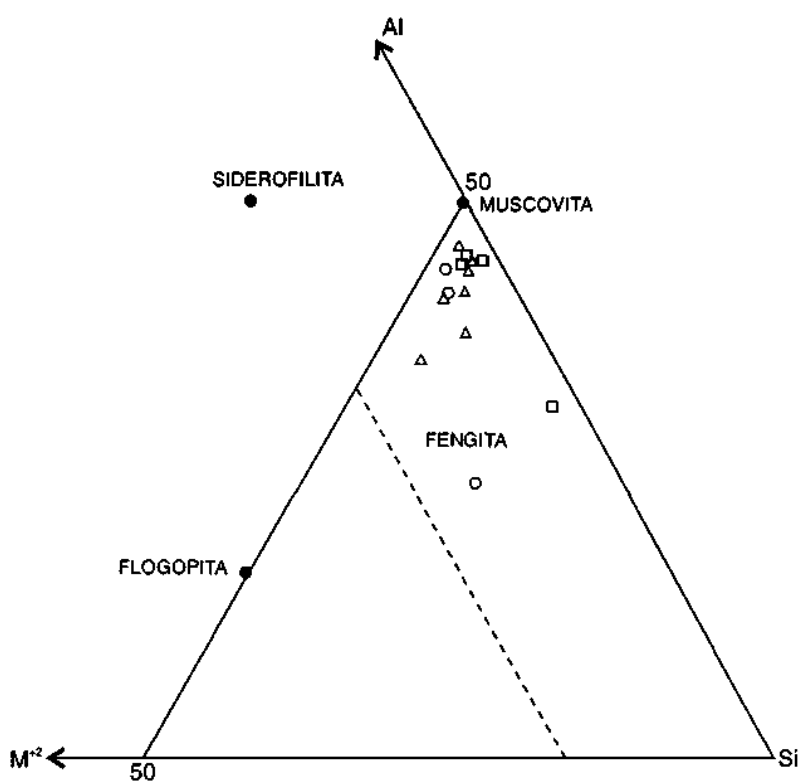

Figura 6 - Composição das micas brancas presentes no granito Pojuca em termos das proporçôes atómicas de Si, Al $M^{+2}=F e_{t}+M g$ (Deer et al. 1992), mostrando tratar-se da variedade fengita.

$\mathrm{O}=$ derivada da biotita; $\quad=$ derivada do plagioclásio; $\mathrm{A}=$ presente em veios/vênulas

Tabela 4 - Composição química (\% em peso) de argilo-minerais e stilpnomelana (STILP) do granito Pojuca, Serra dos Carajás (PA). NONTR = nontronita $; M O N T=$ montmorilonita $;$ INTERX $=$ interestratificado (clorita-smectita). Mesma legenda da tabela 1.

\begin{tabular}{|c|c|c|c|c|c|}
\hline & NONTR & MONT & ILLITA & INTERX & STILP \\
\cline { 2 - 6 } & $(2)$ & $(7)$ & $(2)$ & $(3)$ & $(25)$ \\
\hline $\mathrm{SiO}_{2}$ & 45,37 & 50,15 & 41,33 & 31,20 & 41,78 \\
$\mathrm{TiO}_{2}$ & 0,13 & 0,04 & - & - & tr \\
$\mathrm{Al}_{2} \mathrm{O}_{3}$ & 13,66 & 18,18 & 28,68 & 23,69 & 6,64 \\
$\mathrm{Fe}_{2} \mathrm{O}_{3(0)}$ & 13,17 & 5,68 & 18,34 & 26,11 & 34,05 \\
$\mathrm{MnO}$ & 0,03 & 0,02 & 0,21 & 0,48 & 0,68 \\
$\mathrm{MgO}$ & 3,45 & 2,45 & 4,48 & 6,42 & 1,18 \\
$\mathrm{CaO}$ & 1,27 & 1,07 & 0,07 & 0,07 & 0,16 \\
$\mathrm{Na}_{2} \mathrm{O}$ & 0,13 & 0,04 & 0,13 & 0,12 & 0,41 \\
$\mathrm{~K}_{2} \mathrm{O}$ & 0,88 & 1,23 & 5,56 & 3,36 & 2,14 \\
$\mathrm{La}_{2} \mathrm{O}_{3}$ & - & 0,07 & - & - & 0,04 \\
$\mathrm{Ce}_{2} \mathrm{O}_{3}$ & 0,12 & 0,09 & 0,17 & - & 0,05 \\
$\mathrm{Y}_{2} \mathrm{O}_{3}$ & 0,05 & 0,01 & 0,07 & 0,06 & 0,03 \\
$\mathrm{UO}_{2}$ & 0,01 & tr & 0,13 & - & 0,04 \\
$\mathrm{ThO}_{2}$ & 0,07 & 0,04 & 0,01 & tr & 0,04 \\
$\mathrm{Total}_{0}$ & 78,34 & 79,07 & 99,18 & 91,51 & 87,24 \\
\hline
\end{tabular}

rência de cinco diferentes minerais nas rochas do granito Pojuca, nos quais o ítrio e/ou as terras raras são importantes constituintes: hellandita, caysichita, gadolinita, sinchisita e policrásio, cujas fórmulas químicas respectivas são $\left[(\mathrm{Ca}, \mathrm{Y})_{6}\left(\mathrm{Al}_{1}, \mathrm{Fe}^{+3}\right) \mathrm{Si}_{4} \mathrm{~B}_{4} \mathrm{O}_{20} \cdot(\mathrm{OH})_{4}\right],\left[(\mathrm{Y}, \mathrm{Ca})_{4}\right.$ $\left.\mathrm{Si}_{4} \mathrm{O}_{10}\left(\mathrm{CO}_{3}\right) 3.4 \mathrm{H}_{2} \mathrm{O}\right], \quad\left[(\mathrm{Y}, \mathrm{TR})_{2} \mathrm{FeBe}_{2} \mathrm{Si}_{2} \mathrm{O}_{10}\right], \quad\left[(\mathrm{Ce}, \mathrm{La}) \quad \mathrm{FCO}_{3} \cdot \mathrm{CaCO}_{3}\right]$ e $\left[(\mathrm{Y}, \mathrm{Ca}, \mathrm{Ce}, \mathrm{U}, \mathrm{Th})(\mathrm{Ti}, \mathrm{Nb}, \mathrm{Ta})_{2} \mathrm{O}_{6}\right.$. A identificação da hellandita foi confirmada por difratometria de Raios-X, enquanto a da caysichita é ainda duvidosa, embora dados espectrométricos RAMAN tenham detectado a presença de carbonato e água.

A hellandita é um mineral muito raro, mas tem sido descrito em pegmatitos e granitos de várias partes do mundo (Hogarth et al 1972, Mellini \& Merlino 1977). A caysichita é um mineral ainda mais raro e, de nosso conhecimento, foi descrito pela primeira e única vez em um pegmatito granítico localizado ao norte de Ottawa, Canadá (Hogarth et al. 1974). Já a gadolinita é também um mineral raro e tem composição química variável decorrente da solução sólida (provavelmente parcial) entre $\mathrm{FeLn}_{2} \mathrm{Be}_{2} \mathrm{Si}_{2} \mathrm{O}_{10}-\mathrm{FeCaLnBe}_{2} \mathrm{Si}_{2} \mathrm{O}_{10^{-}}$ $\mathrm{H}_{2} \mathrm{Ln}_{2} \mathrm{Be}_{2} \mathrm{Si}_{2} \mathrm{O}_{10}$, onde $\mathrm{Ln}$ representa o $\mathrm{Y}$ e os lantanídeos (Ito \& 
Tabela 5 • Composição química (\% em peso) de minerais ricos em $Y$, $T R$, Th e U, granito Pojuca, Serra dos Carajás (PA). HELLA = hellandita; $C A Y S=$ caysichita; $G A D O L=$ gadolinita; $S Y N C H=$ sinchisita; $P O L I C=$ policrásio; $M I C R O=$ microlita; $T O R O G=$ torogumita. Mesma legenda da tabela 1.

\begin{tabular}{|c|c|c|c|c|c|c|c|}
\hline & HELLA & CAYS & GADOL & SINCH & POLIC & MICRO & TOROG \\
\hline & (16) & (17) & (9) & (4) & (5) & (5) & (13) \\
\hline $\mathrm{SiO}_{2}$ & 23,18 & 34,60 & 22,92 & 0,59 & 0,51 & $=$ & 21,96 \\
\hline $\mathrm{TiO}_{2}$ & 0,01 & 0,01 & tr & - & 36,39 & 6,65 & 0,05 \\
\hline $\mathrm{UO}_{2}$ & nd & nd & nd & tr & 6,63 & 5,89 & 5,18 \\
\hline $\mathrm{ThO}_{2}$ & 0,05 & 0,15 & 0,07 & 1,04 & 1,94 & 0,01 & 42,28 \\
\hline $\mathrm{Nb}_{2} \mathrm{O}_{3}$ & nd & nd & nd & nd & 7,38 & 12,86 & nd \\
\hline $\mathrm{Ta}_{2} \mathrm{O}_{5}$ & nd & nd & nd & nd & 1,31 & 52,98 & nd \\
\hline $\mathrm{Al}_{2} \mathrm{O}_{3}$ & 3,32 & 0,01 & 0,52 & 0,07 & 0,02 & 0,08 & 1,66 \\
\hline $\mathrm{Y}_{2} \mathrm{O}_{3}$ & 27,00 & 27,90 & 35,45 & 4,09 & 18,15 & nd & 8,47 \\
\hline $\mathrm{La}_{2} \mathrm{O}_{3}$ & 0,10 & 0,04 & 0,15 & 9,62 & tr & Ir & 0,16 \\
\hline $\mathrm{Ce}_{2} \mathrm{O}_{3}$ & 0,12 & 0,14 & 0,11 & 28,25 & 0,27 & 0,17 & 0,71 \\
\hline $\mathrm{TR}_{2} \mathrm{O}_{3}$ & 8,86 & nd & 10,48 & nd & 8,55 & nd & 3,43 \\
\hline $\mathrm{Fe}_{2} \mathrm{O}_{40}$ & 1,95 & 0,20 & 11,08 & tr & 2,25 & 0,74 & 0,79 \\
\hline $\mathrm{MnO}$ & 0,74 & 0,03 & 0,01 & - & 0,34 & - & 0,26 \\
\hline $\mathrm{MgO}$ & $>0,01$ & - & 0.16 & - & - & 0,01 & 0,01 \\
\hline $\mathrm{CaO}$ & $13,9]$ & 16,25 & 2,90 & 20,02 & 2,44 & 18,24 & 1,02 \\
\hline $\mathrm{PbO}$ & $\mathbf{n d}$ & nd & 0,19 & nd & 0,35 & 0,42 & 0,38 \\
\hline $\mathrm{Na}_{2} \mathrm{O}$ & 0,18 & 0,09 & 0,03 & - & 0,03 & 0,93 & $>0,01$ \\
\hline $\mathrm{K}_{2} \mathrm{O}$ & 0,11 & T & 0,17 & 0,01 & 0,02 & 0,04 & 0,09 \\
\hline $\mathrm{H}_{2} \mathrm{O}^{*}$ & 8,54 & 10,05 & nd & ind & nd & nd & ind \\
\hline$F$ & 0,16 & 0,08 & nd & nd & nd & 4,08 & 0,46 \\
\hline$F=0$ & $-0,06$ & $-0,03$ & 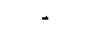 & + & - & $-1,72$ & $-0,19$ \\
\hline Total & 88,17 & 89,34 & 84,24 & 63,69 & 86,58 & 101,38 & 86,72 \\
\hline
\end{tabular}

$\mathrm{TR}_{2} \mathrm{O}_{3}=$ Outras terras raras; $\mathrm{H}_{2} \mathrm{O}^{*}=$ água molecular calcula

Hafner 1974). A gadolinita do granito Pojuca pode ser classificada como cálcio-gadolinita, haja vista seu teor de $\mathrm{CaO}$ em torno de $3 \%$.

Em uma única amostra (NV-09), as análises químicas revelaram a presença de um titano-niobato que foi atribuído à série policrásio [(Y,Ca,TR,U,Th)(Ti,Nb,Ta)2O6]-euxenita $[(\mathrm{Y}, \mathrm{Ca}, \mathrm{TR}, \mathrm{U}, \mathrm{Th})$

$(\mathrm{Nb}, \mathrm{Ta}, \mathrm{Ti})_{2} \mathrm{O}_{6}$. O teor de $\mathrm{TiO}_{2}$ que é mais de quatro vezes superiores a NteOs + Ta2Os (Tab. 5), indica tratar-se de policrásio, o qual é rico em $\mathrm{Y}_{2} \mathrm{O}_{3}, \mathrm{UO}_{2}$ e $\mathrm{TR}_{2} \mathrm{O}_{3}$, o último alcançando cerca de $9 \%$ com destaque para o teor de $\mathrm{Yb} 2 \mathrm{Os}(2,25 \%)$

A análise parcial apresentada na quarta coluna da tabela 5 corresponde a um mineral não silicático rico em $\mathrm{Ca}, \mathrm{Ce}, \mathrm{La}$ e $\mathrm{Y}$. A presenca de carbonato e de flúor nos fluidos hidrotermais, que é evidenciada pela abundante precipitação de calcita e fluorita em vários sítios do granito Pojuca, permite especular que se possa tratar de um flúor-carbonato do grupo da bastnaesita. Aqueles elementos são componentes principais tanto da parisita como da sinchisita, mas o teor de $\mathrm{CaO}$ encontrado favorece nitidamente a estequiometria desta última.

MINERAIS DE U E/OU Th Como principal representante desse grupo figura a torogumita, que é um silicato de tório $\left[\mathrm{Th}\left(\mathrm{SiO}_{4}\right)_{1} \mathrm{O}_{\mathrm{x}} \mathrm{OH}_{4}\right.$ com U (até 31\%), Pb e TR (Branco 1982) derivado da alteração da torita e uranotorita, ambas presentes como minerais magmáticos no granito Pojuca. As análises químicas (Tab. 5) mostram razões de $\mathrm{ThO}_{2}$ $\mathrm{UO}_{2}$ iguais a 5,6, além de expressivas quantidades de $\mathrm{Y}_{2} \mathrm{O}_{3}(7,4$ a $8,9 \%$ ) e de terras raras (cerca de 4,5\%). Esses dados são consistentes com análises de torita metamíctica encontrados na literatura (Pagel 1982), salvo pelos teores de Y o qual, no granito Pojuca, deve ter entrado na estrutura da torita e uranotorita substituindo o Th.

MICROLITA Trata-se de um tantalato da série pirocloro (Na$\left.\mathrm{CaNb}_{2} \mathrm{O}_{6} \mathrm{~F}\right)$ - microlita $\left[\mathrm{NaCaTa}_{2} \mathrm{O}_{6}(\mathrm{O}, \mathrm{OH}, \mathrm{F})\right]$ encontrado na amostra proveniente da porção pegmatóide do contato entre o corpo granítico e os anfibólio xistos encaixantes. A grande predominância do Ta sobre o Nb justifica a identificação como microlita, cuja análise (Tab. 5), além dos componentes essenciais, revelou também altos teores deTiO e $\mathrm{UO}_{2}$, este último, em particular, reforçando a favorabilidade do granito Pojuca à concentração de urânio, que, como já foi visto, está presente em outros minerais acessórios.

MINERAIS DE B E Be Embora sem determinações de B e Be, as propriedades ópticas e a paragênese permitiram identificar nesse grupo a turmalina e a bavenita $\left[\mathrm{Ca}_{4} \mathrm{Be}_{2} \mathrm{Al}_{2}\left(\mathrm{SiO}_{3}\right)_{9} \cdot \mathrm{xH}_{2} \mathrm{O}\right]$, o que foi consubstanciado pelos resultados das análises feitas para os elementos nãovoláteis principais (Tab. 6).

A turmalina é a variedade schorlita com composição heterogénea devida à variação nos teores de $\mathrm{FeOt}$ e $\mathrm{MgO}$, os quais conferem para as três amostras analisadas valores da fração molar Fe $\left(\mathrm{Fe}^{+2}+\mathrm{Mg}+\right.$
Tabela 6 - Composição química (\%empeso) parcial ou total de zircão (ZIRC), apatita (APAT), turmalina, bavenita (BAVEN) e pirofanita (P IRO F) presentes no granito Pojuca, Serra dos Carajás (PA). Mesma legenda da tabela 1.

\begin{tabular}{|c|c|c|ccc|c|c|}
\hline & ZIRC & APAT & \multicolumn{3}{|c|}{ TURMALINA } & BAVEN & PIROF \\
\cline { 2 - 8 } & $(16)$ & $(9)$ & $(5)$ & $(6)$ & $(9)$ & $(10)$ & $(3)$ \\
\hline $\mathrm{SiO}_{2}$ & 34,09 & 0,35 & 33,49 & 34,97 & 34,46 & 56,57 & 0,05 \\
$\mathrm{TiO}_{2}$ & 0,02 & 0,04 & 0,96 & 0,03 & 0,33 & 0,02 & 52,67 \\
$\mathrm{ZrO}_{2}$ & 45,54 & nd & nd & nd & nd & nd & nd \\
$\mathrm{UO}_{2}$ & 0,31 & 0,03 & 0,05 & nd & 0,05 & 0,03 & nd \\
$\mathrm{ThO}_{2}$ & 0,07 & 0,04 & 0,03 & 0,04 & 0,02 & 0,01 & $>0,01$ \\
$\mathrm{Al}_{2} \mathrm{O}_{3}$ & 0,38 & - & 29,55 & 31,87 & 29,73 & 9,09 & $>0,01$ \\
$\mathrm{Y}_{2} \mathrm{O}_{3}$ & 1,02 & 0,32 & nd & nd & nd & nd & $>0,01$ \\
$\mathrm{La}_{2} \mathrm{O}_{3}$ & 0,07 & 0,17 & tr & 0,15 & 0,01 & 0,03 & 0,12 \\
$\mathrm{Ce}_{2} \mathrm{O}_{3}$ & 0,18 & 0,40 & tr & - & 0,14 & 0,05 & 0,06 \\
$\mathrm{FeO}_{40}$ & 0,54 & 0,06 & 17,91 & 18,00 & 11,91 & 0,01 & 33,57 \\
$\mathrm{MnO}$ & 0,10 & 0,07 & 0,05 & 0,06 & 0,04 & 0,01 & 14,64 \\
$\mathrm{MgO}$ & 0,01 & - & 8,02 & 0,09 & 4,47 & - & 0,02 \\
$\mathrm{CaO}$ & 1,01 & 53,29 & 0,52 & 0,22 & 1,02 & 23,30 & 0,09 \\
$\mathrm{Na}_{2} \mathrm{O}$ & $>0,01$ & 0,05 & 2,13 & 2,44 & 2,14 & 0,02 & 0,03 \\
$\mathrm{~K} \mathrm{O}$ & 0,02 & - & 0,07 & 0,04 & 0,02 & 0,01 & $>0,01$ \\
$\mathrm{~F}$ & nd & nd & nd & 1,61 & 0,77 & 0,39 & nd \\
$\mathrm{F}=\mathrm{O}$ & - & - & - & $-0,68$ & $-0,32$ & $-0,16$ & - \\
$\mathrm{Total}$ & 83,36 & 54,82 & 92,71 & 88,89 & 84,79 & 89,38 & 101,25 \\
\hline
\end{tabular}

$\mathrm{A} 1^{\mathrm{VI}}$ ) iguais a $0,55,0,99$ e 0,45 , cada um correspondendo a um modo de ocorrência. A primeira parece ser de origem pneumatolítica com seus cristais ocupando os espaços intergranulares dos feldspatos ou substituindo-os. A outra faz parte de um veio de cerca de $8 \mathrm{~mm}$ de espessura encaixado no granito, estando associada a quartzo, fengita e molibdenita. Já a última ocorre na fracão pegmatóide em contato com os anfibolitos encaixantes em coexistência com bavenita, quartzo e plagioclásio. As marcantes diferenças químicas dessas três variedades de turmalina retraiam as contrastantes condicões reinantes nos ambientes magmático e hidrotermal, e, naquele, as prevalecentes nos estágios pneumatolítico e pegmatítico em conjunção com o quimismo do local da ocorrência.

A bavenita é outro mineral raro, tendo sido descrita em bem poucas localidades (Fleicher \& Switzer 1957, Switzer \& Reichen 1960, Manning et al. 1983), mas todas em corpos pegmatíticos derivados de intrusões graníticas. Bem provavelmente, a bavenita do granito Pojuca é a primeira a ser descrita no Brasil e faz parte de um veio pegmatítico associada à turmalina e quartzo no contato entre aquele granito e os anfibólio xistos do grupo encaixante homónimo. A composição química (Tab. 6) é inteiramente compatível com as existentes na literatura, mas registra-se pequena deficiência em $\mathrm{Al}(1,73$ átomos para uma base de 25 átomos de oxigénio) o qual deve ter sido parcialmente substituído por $\mathrm{Be}+\mathrm{H}$.

ZIRCÃO E APATITA Análises parciais de zircão e apatita encontramse na tabela 6. Os teores de $\mathrm{SiO}_{2}$ do zircão aproximam-se dos valores estequiométricos com desvio máximo de $10 \%$. Já os teores de $\mathrm{ZrO}_{2}$ são cerca de 30 a $34 \%$ mais baixos, implicando certamente a presença de háfnio que não foi analisado e é o elemento que mais comumente substitui o Zr. Outros componentes estão presentes em quantidades às vezes acima de $0,5 \%$ como é o caso do $\mathrm{Y}_{2} \mathrm{O}_{3}, \mathrm{Al}_{2} \mathrm{O}_{3}, \mathrm{UO}_{2}$ e $\mathrm{CaO}$, este último podendo chegar a quase $2 \%$, o que pode indicar leve alteracão favorecida pela metamictização. Os óxidos de terras raras $(\mathrm{La}, \mathrm{Ce}, \mathrm{Nd}$, $\mathrm{Pr}$, Lu e Yb) chegam a alcançar $0,65 \%$.

Em uma única amostra foram analisados cristais de apatita na qual eles são, contrariando as observações gerais, relativamente abundantes. O teor da $\mathrm{CaO}(53,23 \%)$ afasta-se um pouco do valor estequiométrico $(55,82 \%)$ consoante com a presença de impurezas representadas por $\mathrm{Si}, \mathrm{Y}, \mathrm{Ce}$ e La, que normalmente substituem o $\mathrm{Ca}$.

CALCITA E FLUORITA Os resultados analíticos parciais mostram calcita e fluorita quase puras, com teores de $\mathrm{Ca}$ que pouco se desviam dos valores estequiométricos. As maiores impurezas na calcita referem-se à substituição do $\mathrm{Ca}$ por $\mathrm{Fe}, \mathrm{Mn}$, Ce e $\mathrm{La}$ que juntos, em termos de óxidos, somam no máximo $1,5 \%$ em duas amostras. Nas outras duas, esses componentes ficam abaixo de $0,3 \%$. Em uma amostra (NV-17) o teor de flúor é significativo e consentâneo com a presença comum de fluorita dentre os minerais de alteração. Nos cristais de fluorita analisados as impurezas não são relevantes, mas em algumas delas detectam-se quantidades razoáveis de $\mathrm{Si}, \mathrm{Al}, \mathrm{Fe}, \mathrm{La}, \mathrm{Ce}$ ou $\mathrm{Y}$ que, entretanto, em conjunto, não atingem $1 \%$. 
Esses dados mostram, em particular, como já antecipado pela precipitação de minerais ricos em elementos terras raras e ítrio, condições favoráveis à mobilidade desses elementos no sistema hidrotermal Pojuca.

ÓXIDOS E SULFETOS No grupo dos óxidos foram analisados rutilo, magnetita e pirofanita (Tab. 6). No rutilo chama atenção a entrada de $\mathrm{Fe}$ em proporções que podem passar de $2 \%$ como $\mathrm{FeO}_{t}$, bem como a de $\mathrm{Ca}$ embora em quantidades menores $(>1 \% \mathrm{CaO})$. Já na magnetita são o $\mathrm{Ti}, \mathrm{Si}, \mathrm{Ca}$ e $\mathrm{Al}$ os elementos responsáveis pelas maiores substituições do Fe, porém não representam nem $2 \%$ do peso total do mineral na forma de óxidos. A pirofanita é membro da solução sólida ilmenita-pirofanita $(\mathrm{Fe}, \mathrm{Mn}) \mathrm{TiO}_{3}$, sendo muito rara no granito Pojuca. Ocorre como produto local de alteração de fase máfíca em uma excepcional circunstância de alta concentração de manganês em um sistema que, como um todo, mostra-se bastante pobre neste elemento. Dentre os sulfetos foram analisados a calcopirita e a pirita, ambas com alto grau de pureza conforme pode-se deduzir de suas fórmulas estruturais representadas respectivamente por $\mathrm{Cu}_{0,98} \mathrm{Fe}_{1,02-1,03} \mathrm{~S}_{2}$ e Feo,99S2. Quantidades significativas de elementos traços somente foram determinadas para $\mathrm{Pb}$ e, às vezes, para $\mathrm{Bi}$ na faixa de $1000 \mathrm{a}$ 1600 ppm.

A Variabilidade Composicional dos Minerais A formação e as características químicas dos minerais de alteração são controladas fundamentalmente pela temperatura, pressão e composição química das soluções hidrotermais e das rochas através das quais elas migram, além das razões fluido/rocha. Durante a evolução de um sistema hidrotermal formam-se diferentes minerais, alguns com ampla variação composicional refletindo condições particulares sob as quais eles foram precipitados. Os processos hidrotermais são, assim, dependentes da trajetória das soluções e as reações químicas correspondentes governadas pela distribuição e geometria dos poros que, em última análise, definem a área de contato entre os minerais e os fluidos. Em corpos plutônicos é comum observar-se blocos de rocha limitados por fraturas contínuas no interior dos quais muitos produtos da alteração espelham fortemente a composição dos minerais substituídos. As soluções aquosas, que saturam os poros, funcionam como meio estacionário para a difusão das espécies iônicas, a qual, naqueles blocos, se torna o mais importante mecanismo de transferência de massa entre soluções e rocha. Ao longo das fraturas, o transporte se dá prioritariamente por fluxo e a precipitação dos minerais é muito dependente da composição dos fluidos e dos gradientes de temperatura e pressão. Entre essas duas situações extremas, há aquelas intermediárias em que o controle da precipitação e composição dos minerais é exercido também por outros parâmetros.

A variabilidade composicional do minerais é pois um resultado previsível da alteração hidrotermal e as associações minerais dependem, para uma dada temperatura e pressão, da composição da solução que muda, temporal e espacialmente, com o progresso da reação (Helgeson 1970). É esperado assim que, em distintos domínios do corpo rochoso, fases mineralógica ou quimicamente diferentes se estabilizem.

No granito Pojuca, em que as razões fluido/rocha não foram elevadas, os dados mineralógicos e químicos indicam que muitas reações foram tamponadas pelos minerais. O exemplo mais marcante é o da biotita, cujos componentes foram redistribuídos pela clorita, feldspato potássico, titanita e óxidos de ferro em substituição pseudomórfica àquela mica. Decorrem daí os altos teores de $\mathrm{FeO}_{\mathrm{t}}$ do feldspato potássico e os de $\mathrm{Al}_{2} \mathrm{O}_{3}$ e $\mathrm{FeO}_{4}$ da titanita, particularmente se comparados com aqueles das variedades presentes em vênulas. Já a clorita mostra razões de $\mathrm{Fe} /(\mathrm{Fe}+\mathrm{Mg})$ entre 0,87 e 0,99 , refletindo, talvez, as altas frações molares do componente annita da biotita ígnea. Em três amostras, porém, aquelas razões ficaram entre 0,65 e 0,76 , o que pode significar maior influência dos fluidos ou mesmo formação a diferentes temperaturas (Cathelineau \& Nieva 1985).

Outro exemplo marcante é o das fengitas resultantes da alteração da biotita e do plagioclásio. A primeira é enriquecida em FeOt $(3,81$ a $8,53 \%$ ) e tem ampla variação de $\mathrm{Al}_{2} \mathrm{O}_{3}(17,58$ a $33,51 \%)$, enquanto a outra é bem mais empobrecida em FeOt (1,61 a 2,96\%) e apresenta menor variação de $\mathrm{Al}_{2} \mathrm{O}_{3}(22,48$ a $33,91 \%)$.

A existência de Fe-chamosita e de Mg-chamosita como produtos da alteração do feldspato potássico e de Fe-chamosita derivada do plagioclásio evidencia que o controle composicional deve ter sido exercido mais pelas soluções hidrotermais do que pelo mineral substituído. Como ambos os tipos de clorita ocorrem também em vênulas, pode-se inferir fluidos com diferentes razões entre as atividades de $\mathrm{Fe}^{++}$e $\mathrm{Mg}^{++}$
Os dados sobre a pistacita são também ilustrativos. A de composição mais homogénea é a que manteia/substitue a alanita, em contraste com a que substitue o plagioclásio ou é encontrada em vênulas. As maiores variações, contudo, são verificadas nos teores de $\mathrm{Fe}_{2} \mathrm{O}_{3(\mathrm{t})} \mathrm{e} \mathrm{Al}_{2} \mathrm{O}_{3}$. Nas primeiras as diferenças entre esses componentes, individualmente, não ultrapassam $1,1 \%$, enquanto que nos outros dois tipos os teores de $\mathrm{F}_{\mathrm{e} 2} \mathrm{O}_{3(\mathrm{t})}$ e $\mathrm{Al}_{2} \mathrm{O}_{3}$ variam, em relação antipatética, respectivamente, de 20,38 a $25,86 \%$ e de 22,75 a $26,73 \%$. Isso indica que a composição da pistacita independeu em grande parte do modo de ocorrência e deve ter sido regulada bem mais pela fugacidade de oxigénio e quimismo das soluções hidrotermais do que pela composição das fases primárias que se alteraram para epídoto.

Outro óbvio exemplo da importância majoritária dos fluidos está na incomum substituição do quartzo por calcita, com a reação incongruente tendo sido processada em locais onde as soluções aquosas devem ter adquirido caráter alcalino e eram ricas em espécies carbonáticas.

CONTROLES QUÍMICOS DA ALTERAÇÃO HIDROTERMAL As observações feitas durante este trabalho referem-se à cúpula do granito Pojuca e cobrem seções até $20 \mathrm{~m}$ de profundidade a partir do contato. Essa zona, ainda que não densamente fraturada, deve ter tido suficiente permeabilidade para permitir a circulação dos fluidos que deram origem aos veios/vênulas hidrotermais lá presentes. Estudos em inclusões fluidas combinados com evidências texturais e mineralógicas (Villas, em preparação) sugerem que os fluidos aquosos que alteraram as rochas do granito Pojuca tiveram origem diversa, com contribuições magmática, conata e até mesmo meteórica. Quimicamente esses fluidos correspondem ao sistema $\mathrm{NaCl}-\mathrm{CaCl}_{2}-\mathrm{FeCl}_{2}$ $\left(\mathrm{MgCl}_{2}\right)-\mathrm{H}_{2} \mathrm{O}$ nos quais outros íons também se fizeram presentes, em particular espécies de F, Y e ETR.

O Equilíbrio no Sistema Hidrotermal Pojucr Apesar de ubíqua, a ponto de toda amostra de rocha examinada apresentar algum sinal de metassomatismo, a alteração é fraca com estimativas volumétricas de até $10 \%$. As razões fluido/rocha devem ter sido baixas ou as soluções não possuíam grande poder de reatividade, tendo, assim, destruído pouca quantidade de minerais primários e, em consequência precipitado proporções relativamente pequenas de minerais de alteração. Os halos de alteração ao longo dos veios estão ausentes ou são muito pouco desenvolvidos, indicando que as soluções e as rochas devem ter estado próximas do equilíbrio químico. É sintomático que quartzo, feldspato potássico e albita componham tanto as associações primárias como as secundárias, ou seja, os principais minerais reagentes ( $>95 \%$ do volume da rocha) figuram também como produtos da alteração hidrotermal. Mesmo a alanita - importante mineral varietal do granito - e a titanita foram precipitadas como fases secundárias. Tivessem a biotita e a hornblenda também sido produzidas, o equilíbrio geral do sistema poderia ter sido completo. Como esses constituintes máficos são bem pouco abundantes no granito, pode-se, para todos os efeitos práticos, considerar o equilíbrio alcançado.

Parece, dessa forma, que as soluções, pouco ácidas, foram cedo tamponadas pelo granito que a elas, em particular, transferiu $\mathrm{Na}$ e $\mathrm{K}$ para mais tarde serem reincorporados às rochas mediante a precipitação da albita, fengita e, também, do próprio feldspato potássico.

Essa tendência a um equilíbrio geral foi, por outro lado, acompanhada de equilíbrios locais (Ferry 1979, Helgeson 1979), que devem ter sido responsáveis pela grande número de minerais secundários, muitos com expressiva variação composicional, bem como pela rara ocorrência de alguns deles. Além das mudanças de temperatura e pressão, os equilíbrios locais ocorreram em resposta às variações dos potenciais químicos dos componentes da fase aquosa que, certamente, foram afetados .pela composição dos minerais destruídos. A clássica transformação da biotita em clorita $+\mathrm{K}$-feldspato + titanita \pm óxidos opacos (Chayes 1955) exemplifica muito bem um desses equilíbrios locais, junto a outros responsáveis, por exemplo, pela formação da stilpnomelana, pirofanita, gadolinita, sinchisita, hellandita, etc.

A presença de stilpnomelana em apenas uma amostra, mas em abundância, aponta para condições locais extremamente favoráveis à estabilidade desse mineral. É curioso que no veio composto por stilpnomelana + quartzo + calcita \pm albita \pm alanita não tenha havido precipitação nem de fengita nem de clorita - dois dos mais frequentes e abundantes minerais secundários do sistema Pojuca -, e com as quais a stilpnomelana coexiste em associações metamórficas de fácies xisto verde (Turner 1968). Isso reforça a ideia de um microambiente especial marcado por temperaturas relativamente baixas e por fluidos pobres em $\mathrm{Al}$ e K, e francamente oxidantes. No caso particular da composição da pistacita, a ampla variação deve, dentre outros fatores, refletir as 
flutuações da fugacidade de oxigénio no sistema hidrotermal (Bird \& Helgeson 1981). De fato, variações de fo2 são denunciadas desde a substituição da alanita pela pistacita, em que o Fe ${ }^{+2}$ cede lugar ao $\mathrm{Fe}^{+3}$, até os estágios finais que são marcados pela estabilização de hematita. A restrita ocorrência de magnetita e a presença de minerais ricos em $\mathrm{Fe}^{+2}$ como a clorita, além dos sulfetos, indicam valores de fo2 que devem ter ficado próximos ou abaixo do tampão QFM durante a fase principal da alteração hidrotermal. Estimativas dos teores de $\mathrm{Fe}_{2} \mathrm{O}_{3}$ nas cloritas, como base no balanço de carga na posição octaédrica, fornecem valores entre 0,0 e $3,0 \%$.

A Participação das Rochas Encaixantes $O$ magma que deu origem ao granito Pojuca era empobrecido em $\mathrm{CaO}$, tanto que cristalizou plagioclásio com baixo teor da fração anortítica e quantidades subordinadas de minerais contendo $\mathrm{Ca}$ (hornblenda, alanita e titanita). Trabalhos recentes, porém, admitem um plagioclásio primário mais anortítico e com proporções modais médias de $28 \%$ em rochas classificadas de monzogranitos, os quais foram reconhecidos como uma das fácies mais importantes do corpo Pojuca (Horbe 1998). A albita hoje observada $(\mathrm{An}<5)$ seria resultado de descalcificação em resposta aos processos hidrotermais, significando que, para uma composição estimada de $\mathrm{Na}_{0.85} \mathrm{Ca}_{0.15} \mathrm{Al}_{1.15} \mathrm{Si}_{2.85} \mathrm{O}_{8}$ para 0 plagioclásio ígneo, $0,45 \%$ de $\mathrm{Ca}$ poderiam ser disponibilizados para produção de minerais secundários.

Em amostras com minerais de alteração perfazendo cerca de 4\%, aquele autor estimou proporções modais de $0,48 \%, 0,45 \%$ e $0,30 \%$ respectivamente para fluorita, epídoto e calcita, os quais, em conjunto, requereram cerca de $0,45 \%$ de $\mathrm{Ca}$ para sua formação. O oligoclásio sozinho poderia ter sido a fonte desse cálcio, mas tem-se que admitir um processo geoquímico bastante incomum, capaz de descalcificar esse feldspato uniformemente, sem outras transformações de vulto. A saída de cálcio e alumínio do feldspato com subsequente recristalização para albita é um processo difícil de se imaginar em reações hidrotermais incongruentes tipo plagioclásio $\rightarrow$ fluorita $+/$ - epídoto, o que põe em séria dúvida aquela intensa descalcificação e, por extensão, um plagioclásio ígneo fora da faixa composicional da albita $(\mathrm{An}>10)$ Ademais, há rochas com até $1,5 \%$ de fluorita (Horbe 1998), implicando uma disponibilidade de $\mathrm{Ca}$ de $0,8 \%$, a qual é quase o dobro da quantidade potencial liberada pela reação oligoclásio $\rightarrow$ albita.

É bem plausível supor-se que outra fonte importante do cálcio foram as rochas encaixantes dominadas por anfibolitos, hipótese essa que é consonante com a teoria da circulação de fluidos em torno de corpos plutônicos (Norton 1984). No estágio magmático da intrusão Pojuca, o $\mathrm{Ca}$ foi preferencialmente particionado nas fases sólidas (plagioclásio, hornblenda, alanita, titanita, apatita, etc.), de modo que os fluidos residuais se tornaram ainda mais empobrecidos em Ca. Isso é consistente com o fato de eles terem sido capazes de precipitar topázio em vez de fluorita, a qual somente veio a ser depositada, em associação com calcita, epídoto e sulfetos, quando o hidrotermalismo foi dominado pelo influxo de soluções ricas em cálcio oriundas de formações rochosas circunvizinhas ao granito.

Semelhantemente, admite-se que boa parte do Fe também proveio do Grupo Igarapé Pojuca, cuja constituição litológica inclui formações ferríferas bandadas além de outras rochas com abundantes minerais ricos naquele metal. A entrada de ferro pode ter se estendido por grande parte da história hidrotermal, tanto que as soluções aquosas tardias, de baixa salinidade, provocaram variados graus de hematitização das rochas com até mesmo formação local de vênulas de quartzo+hematita+clorita ou de hematita como mineral de saturação em inclusões correspondentes a esses fluidos (Villas, em preparação). É difícil avaliar o balanço de massa do $\mathrm{Mg}$, cujos baixos teores nas rochas alteradas podem corresponder aos teores originais do granito. De fato, a fração molar $\mathrm{Mg} /(\mathrm{Mg}+\mathrm{FeO}$ das cloritas — o único mineral ferro-magnesiano quantitativamente importante nas associações hidrotermais mostra duas faixas distintas de variação, de 0,01 a 0,13 e de 0,28 a 0,35 , com o $\mathrm{Mg}$ da primeira podendo ter sido essencialmente suprido pelas hornblenda e biotita primárias. A faixa mais alta poderia, por outro lado, indicar soluções com maior contribuição de Mg de origem não granítica.

Dessa mesma forma, entende-se o aporte de enxofre que deve ter sido propiciado pela remobilização de sulfetos a partir da mineralização cupro-zincífera presente no Grupo Igarapé Pojuca, os quais foram, mais tarde, reprecipitados nos planos de fraturas abertas na cúpula do granito. Similar interpretação evoca-se para a entrada de carbonatos, mas a rocha-fonte faria parte da Formação Águas Claras cujas fácies mais pelíticas contêm intercalações de carbonatos (rodo- crosita) e são o protominério da mineralização supergênica de Mn da mina do Azul.

O Papel dos Minerais Acessórios Os elementos traços $\mathrm{Zr}$, Th, U, Nb, Ta, Y e TR possuem baixos coeficientes de partição nos principais minerais formadores de rochas e, assim, são preferencialmente incorporados nas fases acessórias. Não raro, essas fases contêm mais de $50 \%$ a quase $100 \%$ dos teores desses elementos nas rochas e, uma vez alteradas, os tornam suscetíveis de mobilização pelas soluções hidrotermais. No granito Pojuca, zircão, torita, uranotorita, policrásio, alanita e titanita são os mais importantes minerais acessórios primários e/ou varietais e, via de regra, mostram-se metamictizados, de cujo processo resultam estruturas progressivamente mais amorfas e liberação de vários dos chamados elementos de HFS (high field strength). Dentre os produtos de alteração, destacam-se, pela frequência e diversidade, minerais portadores de $\mathrm{Ca}, \mathrm{Y}$ e lantanídeos precipitados pelas mesmas soluções que atacaram aquelas fases acessórias magmáticas. A alanita é enriquecida nas terras raras leves, enquanto o policrásio, a uranotorita e a torita concentraram preferencialmente as terras raras pesadas, de modo que podem ser consideradas como fontes adequadas, junto com as contribuições advindas do zircão e titanita, para esses elementos nas quantidades presentes nos minerais hidrotermais ricos em lantanídeos. Há uma clara correspondência no padrão de distribuição de terras raras (Fig. 7) entre as alanitas primária e hidrotermal, bem como entre policrásio/torita/uranotorita e hellandita/gadolinita, o que corrobora serem os minerais primários do granito a principal fonte desses elementos nas soluções hidrotermais. Com a torita e a uranotorita aquela correspondência é menos evidente, devido aos baixos teores de $\mathrm{Yb}$. De modo semelhante, os teores de Y nos minerais acessórios os habilita como a mais importante fonte para a formação dos vários minerais secundários que contêm esse elemento, a exemplo da caysichita(?), gadolinita, hellandita e synchisita.

Essas observações reforçam a crescente evidência de que os ETR e outros elementos traços como Y e Ti podem ser transportados por fluidos hidrotermais (Cathelineau 1987, Gieré 1990) e põem, no mínimo sob cautela, o uso de suas abundâncias como discriminantes geoquímicos da evolução petrogenética e do ambiente tectônico das rochas alteradas, ainda que fracamente. No caso do granito Pojuca, não obstante a evidente mobilização desses elementos, eles foram em grande parte reincorporados às rochas graníticas como produtos de alteração. Fica difícil, contudo, avaliar a extensão dessa redistribuição interna em um sistema aberto às rochas encaixantes, para as quais os fluidos devem também ter sido dirigidos após interação com o granito.

CONCLUSÕES O corpo Pojuca é, dentre as intrusões da suíte anorogênica paleoproterozóica presentes no Distrito Metalogenético de Carajás, até aqui descritas, a única com volume apreciável de álcali-fedspato granitos. Duas fácies, uma leucocrática e outra hololeucocrática, foram distinguidas, a primeira sendo mais enriquecida em minerais máficos, com maiores razões K-feldspato/albita e texturalmente mais grossa e alotriomórfica. Os principais minerais varietais são biotita, alanita e hornblenda, enquanto dentre os acessórios primários destacam-se zircão e titanita, e mais subordinadamente apatita, torita, uranotorita, policrásio e microlita. O topázio está também presente em quantidades acessórias e parece ser o produto que marca a transição entre os estágios essencialmente magmático e hidrotermal.

Essas rochas foram submetidas a uma alteração hidrotermal que, apesar de fraca (razões rocha original/rocha destruída $>0,9$ ), legou uma grande diversidade de minerais secundários, alguns com ampla variação composicional. Destacam-se clorita (Fe- e Mg-chamosita), epídoto, fengita, stilpnomelana e, em particular, minerais ricos em Ca, Y e ETR (hellandita, gadolinita, sinchisita, caysichita?). A presença de quartzo, feldspato potássico, albita, alanita e titanita secundários, bem como a virtual falta de halos de alteração nas paredes dos veios/vênulas são indicativos de que as soluções aquosas e rochas se aproximaram de um equilíbrio químico geral. Muitas fases ou mesmo associações, porém, estabilizaram-se via equilíbrios locais, nos quais ora os minerais destruídos ora a composição dos fluidos, além da temperatura e pressão, foram os agentes controladores mais importantes.

O plagioclásio, de composição albítica, mostra-se pouco alterado e muitos cristais são pelo menos em parte límpidos, impedindo-os, assim, de terem fornecido todo o cálcio que foi necessário para precipitar as proporções modais de epídoto, fluorita e calcita observadas nas rochas do granito Pojuca. Várias evidências suportam terem as rochas encaixantes, ricas em anfibolitos, também suprido esse elemento, que deve ter sido incorporado às rochas graníticas por soluções hidrotermais em resposta a movimentos convectivos que se 


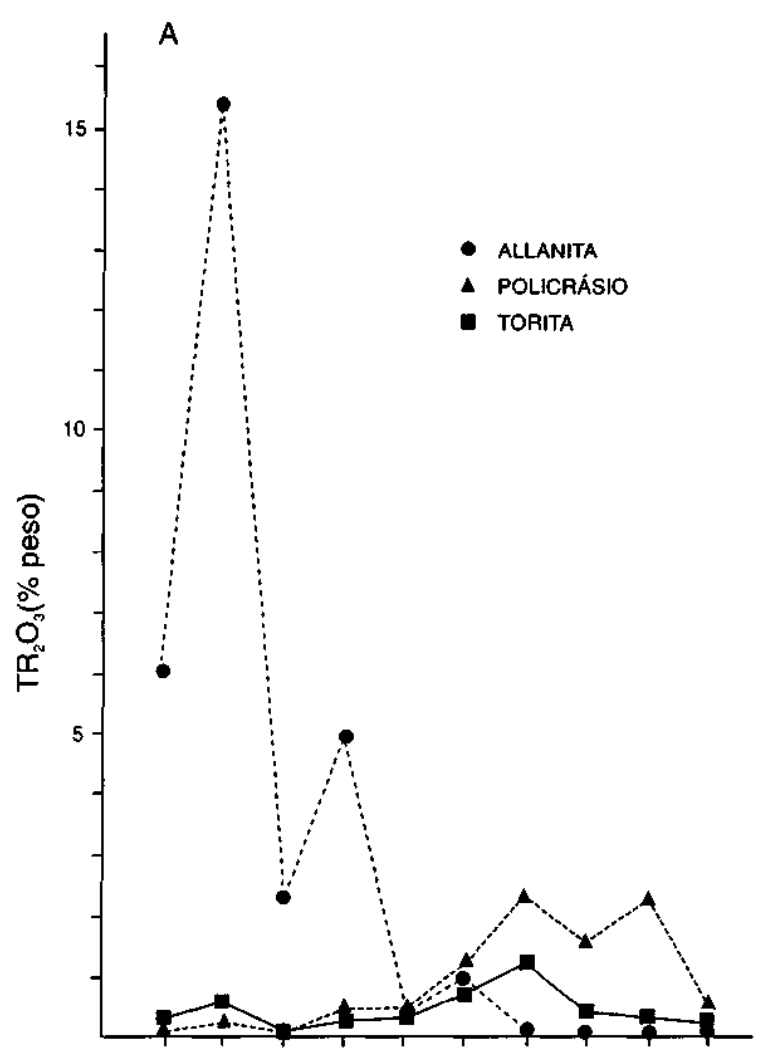

La $\mathrm{Ce} \quad \mathrm{Pr} \quad \mathrm{Nd} \quad \mathrm{Sm}$ Gd Dy $\mathrm{Er} \quad \mathrm{Yb} \quad \mathrm{Lu}$

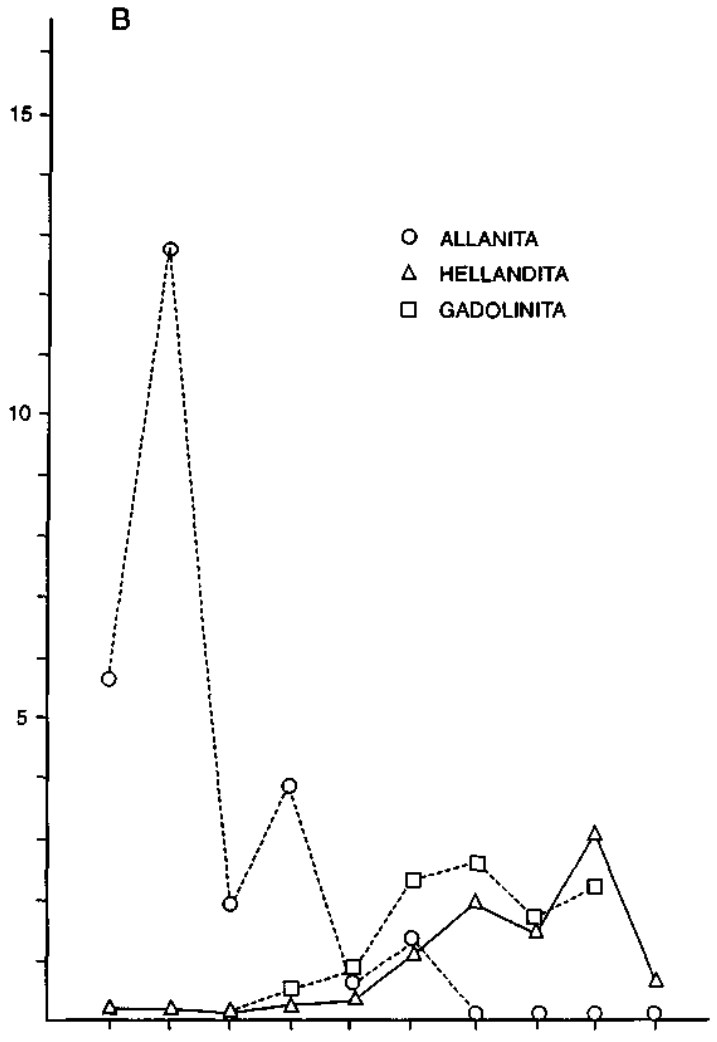

La $\mathrm{Ce} \quad \mathrm{Pr} \quad \mathrm{Nd} \quad \mathrm{Sm} \quad \mathrm{Gd}$ Dy $\mathrm{Er} \quad \mathrm{Yb} \quad \mathrm{Lu}$

Figura 7 - Padrão de distribuição dos elementos terras raras em minerais primários (A) e hidrotermais (B) do granito Pojuca, Serra dos Carajás (PA)

estabelecem comumente em redor de intrusões ígneas. Por outro lado alanita e minerais acessórios ígneos devem ter sido a fonte principal de Y e lantanídeos contidos nas fases secundárias, o que se pode deduzir da grande semelhança no padrão de distribuição dos elementos terras raras que eles apresentam. Fica evidenciado, também, que esses elementos foram altamente móveis no ambiente hidrotermal do granito Pojuca, embora não se tenham dados para avaliar o grau de contaminação por ventura sofrido pelas rochas encaixantes. A extensão dessa contaminação seria de grande valia para, por exemplo, se conhecer o papel que o granito Pojuca possa ter tido com fonte potencial dos elevados teores de terras raras no depósito Bahia, que jaz em proximidade (Villas 1998).
Agradecimentos Este trabalho é resultado de um programa de pós-doutoramento realizado no Centre de Recherches sur Ia Synthése et Chimie dês Mineraux (CRSCM/CNRS), França, sob os auspícios da CAPES. As amostras estudadas foram gentilmente cedidas pela DOCEGEO. A essas entidades sou profundamente grato. Expresso também meu reconhecimento aos Drs. Michel Pichavant, Clairette Ramboz e Claire Beni, e ao técnico de microssonda Olivier Rouer, todos do CRSCM, bem como ao colega Basile Kotschoubey, da UFPA, pelo apoio, incentivo, discussões e críticas construtivas de que muito este trabalho se beneficiou. A dois relatores anónimos da RBG pelas sugestões e críticas.

\section{Referências}

Araújo O.J.B., Maia R.G.N., João X.S.J., Costa J.B.S. 1988. A megaestruturação arqueana da Folha Serra dos Carajás. In. Congresso Latino-americano de Geologia, 7, Belém, Anais, 1:324-338

Bailey S.W. 1988. Chlorites: structures and crystal chemistry. In: Bailey S.W. (ed). Hydrous phyllosilicates (exclusive ofmicas). Mineral. Soe. America, Reviews in Mineralogy, v. 19, p. 347-404

Bird D.K. \& Helgeson H.C. 1981. Chemical interaction of aqueous solutions with epidote-feldspar mineral assemblages in geologic systems. II. Equilibrium constraints in metamorphic/geothermal processes. American Journal of Science, 81:576-614

Branco P.M. 1982. Dicionário de Mineralogia. Porto Alegre. Editora da Univ. Fed. Rio Grande do Sul. 264p

Cathelineau M. 1987. U-Th-REE mobility during albitization and quartz dissolution in granitoids: evidence from southeast French MassifCentral. Bulletin de Minéralogie. 110:249-259

Cathelineau M. \& Nieva D. 1985. A chlorite solid solution geothermometer. The Los Azufres (México) geothermal system. Contributions to Mineralogv and Peírology, 91:235-244

Chayes F. 1955. Potash feldspar as a by-product of the biotite-chlorite transformation. Journal of Geology, 63:75-82

DalFAgnol R., Vieira E., Sá C., Medeiros H., Gastai M.C., Teixeira N.P. 1986. Estado atual do conhecimento sobre as rochas granitóides da porção sul da Amazónia Oriental. Revista Brasileira de Geociências. 16:11-23

Dall'Agnol R., Bettencourt J.S., João X., Medeiros H., Costi H., Macambira M.J.B. 1987. Granitogenesis in the northern Brazilian region: areview. In: Precambrian evolution of the Amazonian region, Final Meeting of the Working Group, Carajás, Pará, Project 204, IUGS-UNESCO. Extended Abstracts, Vol. p. 51-54
Dall'Agnol R., Sauck W. A., Gonçalez M.G.B. 1988. Susceptibilidade magnética em granitóides da Amazónia: um estudo preliminar. In: SBG, Congresso Brasileiro de Geologia, 35, Belém, Anais, 3:1164-1173.

Dali'Agnol R., Lafon J.M., Macambira M.J.B. 1994a. Proterozoic anorogenic magmatism in the Central Amazonian Province, Amazonian Craton: geochronological, petrological and geochemical aspects. Mineralogy and Petrology, 50:113-138

Dall'Agnol R., Scaillet B., Pichavant M. 1994b. Phase relations of amphibole-biotite EMPG

Deer W.A., Howie R.A., Zussman J. 1962. Rock-forming minerais - Sheet silicates. v. 3. London. Longman. 270p.

Deer W.A., Howie R.A., Zussman J. 1966. An introduction to rock-forming minerais. London. Longman. 528p.

Deer W.A., Howie R.A., Zussman J. 1992. An introduction to rock-forming minerais. $2^{\text {nd }}$ Ed., Essex. Longman Scientific \& Technical. 696p.

Docegeo. 1984. Relatório de pesquisa do projeto Cobre Carajás - Pojuca. Volume 1- Texto. Belém. DOCEGEO. 149p.

Docegeo. 1988. Litoestratigrafia e principais depósitos minerais - Província Mineral de Carajás. In: Congresso Brasileiro de Geologia, 35, Belém. Anexo aos anais ... CVRD-SBG. Belém. 165p.

Ferry J. M. 1979. Reactions, mechanisms, physical conditions, and mass transfer during hydrothermal alteration of mica and feldspar in granitic rocks from south-central Maine, USA. Contributions to Mineralogy and. Petrology. 68:125-139

Fleischer M. \& Switzer G. 1953. The bavenite problem. American Mineralogist 38:988-993

Gabis, V. 1979. Chemical analysis. In: Van Olphen H. \& Fripiat J. J. (ed). Data handbook for clay materiais and other non-metallic minerais. Oxford, Pergamon Press. $\mathrm{p}$. $127-153$. bearing granites. I. Effects of amo under oxidizing conditions. Abstracts... London, 
Gieré R. 1990. Hydrothermal mobility of Ti, Zr and REE: examples from the Bergell and Adamello contact aureoles (Italy). Terra Nova 2:60-67

Helgeson H.C. 1970. A chemical and thermodynamic model of ore deposition in hydrothermal systems. Mineralogical Society of America, Special Paper 3:155-186

Helgeson H.C. 1979. Mass transfer among minerais and hydrothermal solutions. In. Barnes H.L. (ed) Geochemistry of hydrothermal ore deposits, New York, John Wiley \& Sons. p. 568-610

Hogarth D.D., Chão G.Y., Harris D.C. 1972. New data on hellandite. Canadian Mineralogist, 11:760-776

Hogarth D.D., Chão G.Y., Plant D.C., Steacy Hr. 1974. Caysichite: a new silico-carbonate of yttrium and calcium. Canadian Mineralogist, 12:293-298

Horbe M.A. 1998. Petrografia e geoquímica do granito Pojuca, Serra dos Carajás - PA. Centro de Geociências, Universidade Federal do Pará, Belém, Tese de mestrado, $135 \mathrm{p}$.

Ito J. \& Hafner S.S. 1974. Synthesis and study of gadolinites. American Mineralogist, 59:700-708

Macambira M.J.B., Ramos J.F.F., Assis J.F.P., Figueiras J.F.M. 1990. Projeto Serra Norte-Projeto Pojuca: Relatório Final. Belém. Centro de Geociências, UFPA 150 p. 4 mapas

Machado N., LindenmayerZ., KrochT.E., LindenmayerD. 1991. U-Pb geochronology of Archean magmatism and basement reactivation in the Carajás área, Amazon Shield, Brazil. Precatnbrian Research, 49:329-354

Magalhães M. S. \& Dall'Agnol R. 1992. Estudos de minerais pesados e susceptibilidade magnética nos granitos Musa e Jamon (Região de Rio Maria - SE do Pará) e suas implicações petrológicas. Revista Brasileira de Geociências, 22:184-197

Manning D.A.C., Putthapiban P., Suensilpong S. 1983. An occurrence of bavenite, $\mathrm{Ca}_{4} \mathrm{Be}_{2} \mathrm{Al}_{2}\left(\mathrm{SiO}_{3}\right)_{9} \cdot \mathrm{xH}_{2} \mathrm{O}$, in Thailand. Mineralogical Magazine, 47:87-89

Medeiros Neto F. A. \& Villas R.N. 1985. Geologia da jazida de Cu-Zn do Corpo 4E-Pojuca, Serra dos Carajás. In: Simpósio de Geologia da Amazónia, 2. Belém. Anais... SBG, Belém. v. 3, p. 97-112

Mellini M. \& Merlino S. 1977. Hellandite: a new type of silicoborate chain. American Mineralogist, 62:89-99

Norton D.L. 1984. Theory of hydrothermal systems. AnnualReview ofEarth andPlanetary Sciences. 12:155-177

Pagel M. 1982. The mineralogy and geochemistry of uranium, thorium, and rare-earth elements in two radioactive granites of the Vosges, France. Mineralogical Magazine, 46:149-161

Pinheiro R.V.L. \& Holdsworth R.E. 1997. Reactivation of Archean strike-slip fault systems, Amazon region, Brazil. Journal of the Geological Society of íWon, 154:99-103
Rios F.J. 1995. A jazida de wolframita de Pedra Preta, granito Musa, Amazónia Oriental (PA): estudos dos fluidos mineralizantes e isótopos estáveis de oxigénio em veios hidrotermais. Centro de Geociências, Universidade Federal do Pará, Belém, Tese de doutorado, $215 \mathrm{p}$.

Rios F.J., Villas R.N., Dall'Agnol R. 1995a. O granito Serra dos Carajás: 1. Fácies petrográficas e avaliação do potencial metalogenético para estanho no setor norte. Revista Brasileira de Geociências, 25:20-31

Rios F.J., Villas R.N., Fuzikawa K. 1995b. O granito Serrados Carajás: 2. Caracterização dos fluidos aquosos e alteração hidrotermal. Revista Brasileira de Geociências, 25:32-40

Scaillet B, Pichavam M, Dall'Agnol R. 1995. Experimental determination of phase equilibria of the Jamon granite, eastern Amazonian province. In: IGCP, Symposium on Rapakivi Granites and Related Rocks, Belém. Abstracts Volume, p. 69.

Shikazono N. 1984. Compositional variations in epidote from geothermal áreas. Geochemical Journal, 18:181-187

Streckeisen H.L. 1976. To each plutonic rock its proper name. Earth Science Reviews, 12:1-33

Switzer G. \& Reichen L.E. 1960. Re-examination of pilinite and its identification with bavenite. American Mineralogist, 45:757-762

Teixeira W., Tassinari C.C.G., Cordani U.G., Kawashita K. 1991. A review of the geochronology of the Amazonian Craton: tectonic implications. Precambrian Research, 42:213-227

Turner F.J. 1968. Metamorphic petrology -mineralogical andfield aspects. New York. McGraw Hill Book Co., 403 p.

Villas R.N. 1998. Granito Pojuca: fonte de elementos terras raras e de urânio do depósito Bahia, Serra dos Carajás? In: SBG, Congresso Brasileiro de Geologia 40, Belo Horizonte, Anais, p. 153

Weaver C. E. \& Pollard L. D. 1973. The chemistry of clay minerais. Developments in Sedimentology 15. Amsterdam, ElsevierSci. Publ. Co. 213p.

Wirth K.R., Gibbs A.K., Olszewski W.J. 1986. U-Pb ages of zircons from the Grão-Pará Group and Serra dos Carajás granite, Pará, Brazil. Revista Brasileira de Geociências, 16(2): 195-200

Manuscrito A-1069

Recebido em 20 de janeiro de 1999

Revisão do autor em 25 de junho de 1999 Revisão aceita em 27 de junho de 1999 